\title{
Tropical Fruits and Their Co-Products as Bioactive Compounds and Their Health Effects: A Review
}

\author{
Sonia Sayago-Ayerdi ${ }^{1}$, Diana Laura García-Martínez ${ }^{1}$, Ailin Cecilia Ramírez-Castillo ${ }^{1}$, \\ Heidi Rubí Ramírez-Concepción ${ }^{1}$ and Manuel Viuda-Martos ${ }^{2, * \mathbb{D}}$
}

1 Tecnologico Nacional de Mexico, Instituto Tecnologico de Tepic, Av Tecnológico 2595, Col Lagos del Country, Tepic 63175, Nayarit Mexico, Mexico; ssayago@tepic.tecnm.mx (S.S.-A.); dilagarciama@ittepic.edu.mx (D.L.G.-M.); aceramirezca@ittepic.edu.mx (A.C.R.-C.); heruramirezco@ittepic.edu.mx (H.R.R.-C.)

2 IPOA Research Group, Centro de Investigación e Innovación Agroalimentaria y Agroambiental (CIAGRO-UMH), Agro-Food Technology Department, Miguel Hernández University, Orihuela, 03312 Alicante, Spain

* Correspondence: mviuda@umh.es; Tel.: +34-966-749-661

check for

updates

Citation: Sayago-Ayerdi, S.; García-Martínez, D.L.; RamírezCastillo, A.C.; Ramírez-Concepción, H.R.; Viuda-Martos, M. Tropical Fruits and Their Co-Products as Bioactive Compounds and Their Health Effects: A Review. Foods 2021, 10, 1952. https://doi.org/10.3390/ foods10081952

Academic Editors: Urszula Tylewicz and Amit K. Jaiswal

Received: 19 July 2021

Accepted: 19 August 2021

Published: 22 August 2021

Publisher's Note: MDPI stays neutral with regard to jurisdictional claims in published maps and institutional affiliations.

Copyright: (c) 2021 by the authors Licensee MDPI, Basel, Switzerland. This article is an open access article distributed under the terms and conditions of the Creative Commons Attribution (CC BY) license (https:// creativecommons.org/licenses/by/ $4.0 /)$

\begin{abstract}
Tropical and subtropical fruits are recognized as a source of a high content of bioactive compounds and health promoting properties due to their nutritional composition. These beneficial health effects are related to the content of several of these bioactive compounds, mainly flavonoids and non-flavonoid phenolics. Many of these compounds are common in different tropical fruits, such as epicatechin in mango, pineapple, and banana, or catechin in pineapple, cocoa or avocado. Many studies of tropical fruits had been carried out, but in this work an examination is made in the current literature of the flavonoids and non-flavonoid phenolics content of some tropical fruits and their coproducts, comparing the content in the same units, as well as examining the role that these compounds play in health benefits.
\end{abstract}

Keywords: flavonoids; phenolic acids; tropical fruits; health; bioactive compounds; anti-carcinogenesis; anti-inflammatory; cardiovascular disease

\section{Introduction}

Tropical fruits are a botanically varied group of fruits originally from tropical and sub-tropical zones. Most of these fruits are comestible and their consumption is growing in both national and international markets owing to the rising recognition of their nutritional and health-promoting properties as well as their organoleptic characteristics including their exclusive taste, sensory properties, and mouthfeel [1]. According to their crop extension, production volumes, and market, tropical fruits may be classified as principal, secondary and wild fruits [2]. The principal fruits include mango (Mangifera indica L.), pineapple (Ananas comosus L. Merr), avocado (Persea americana Mill.), papaya (Carica papaya L.), and banana (Musa paradisiaca L.), among others. Secondary and wild fruits include guava (Psidium guajava L.), tamarind (Tamarindus indica L.), açai (Euterpe oleracea Mart.), purple passion fruit (Passiflora edulis Sims), pomegranate (Punica granatum L.), coconut (Cocos nucifera Linn.), date (Phoenix dactylifera L.), cacao (Theobroma cacao L.), acerola (Malpighia emarginata D.C.), rambutan (Nephelium lappaceum L.), lychee (Litchi chinensis Sonn.), noni (Morinda citrifolia L.), camu-camu (Myrciaria dubia McVaugh), dragon fruit (Hylocereus spp.), mangosteen (Garcinia mangostana L.), goldenberry (Physalis peruviana L.), etc. [3,4].

Therefore, in recent years, the production and commercialization of this type of fruit have increased significantly, estimating an annual growth of around 3.8\% [5]. Approximately, 99\% of tropical fruit production comes from low-income developing countries mainly in Latin America and Caribbean regions. Brazil, Colombia, and Ecuador are the main producers and exporters of tropical fresh fruit worldwide, although there is also a small production from Asiatic and African areas [6]. About 50\% of the tropical and subtropical fruit production is intended for the fresh fruit market, and 50\% is used in numerous 
processed forms (desserts, nectars, compotes, marmalades, sauces, syrups, snacks, jellies, flours, and wines), the most important being tropical fruit beverages [7]. Nutrient-rich juices obtained from tropical fruits are gaining acceptance owing to the desire of consumers for healthy products whilst experiencing new and exotic flavors, and at the same time due to the focus of industry on producing beverages with health claims as a parameter of differentiation [8]. This fact is also influenced by the growing interest on the part of consumers in how fruits and their derivatives can help maintain health, and the role that diet plays in the prevention and treatment of many diseases [9].

Beyond their macro- and micronutrient contents, the edible and non-edible parts of tropical fruits are an important source of numerous bioactive compounds including carotenoids, sterols and stanols, phenolic compounds such as flavonoids and non-flavonoids phenolics $[6,10,11]$, and the dietary fiber content. In recent years, the flavonoids and non-flavonoids phenolics, in all their types and structures (Figure 1), obtained from tropical fruits and their coproducts have aroused the interest of different fields, such as biomedical science and food technology. This interest in these bioactive compounds is due to their numerous biological effects including antioxidant [12,13], hypo-cholesterolemic [14,15], anticancer [16,17], immunomodulatory [18], anti-inflammatory [19,20], anti-diabetic [21,22] and anti-hypertensive $[23,24]$, among others.

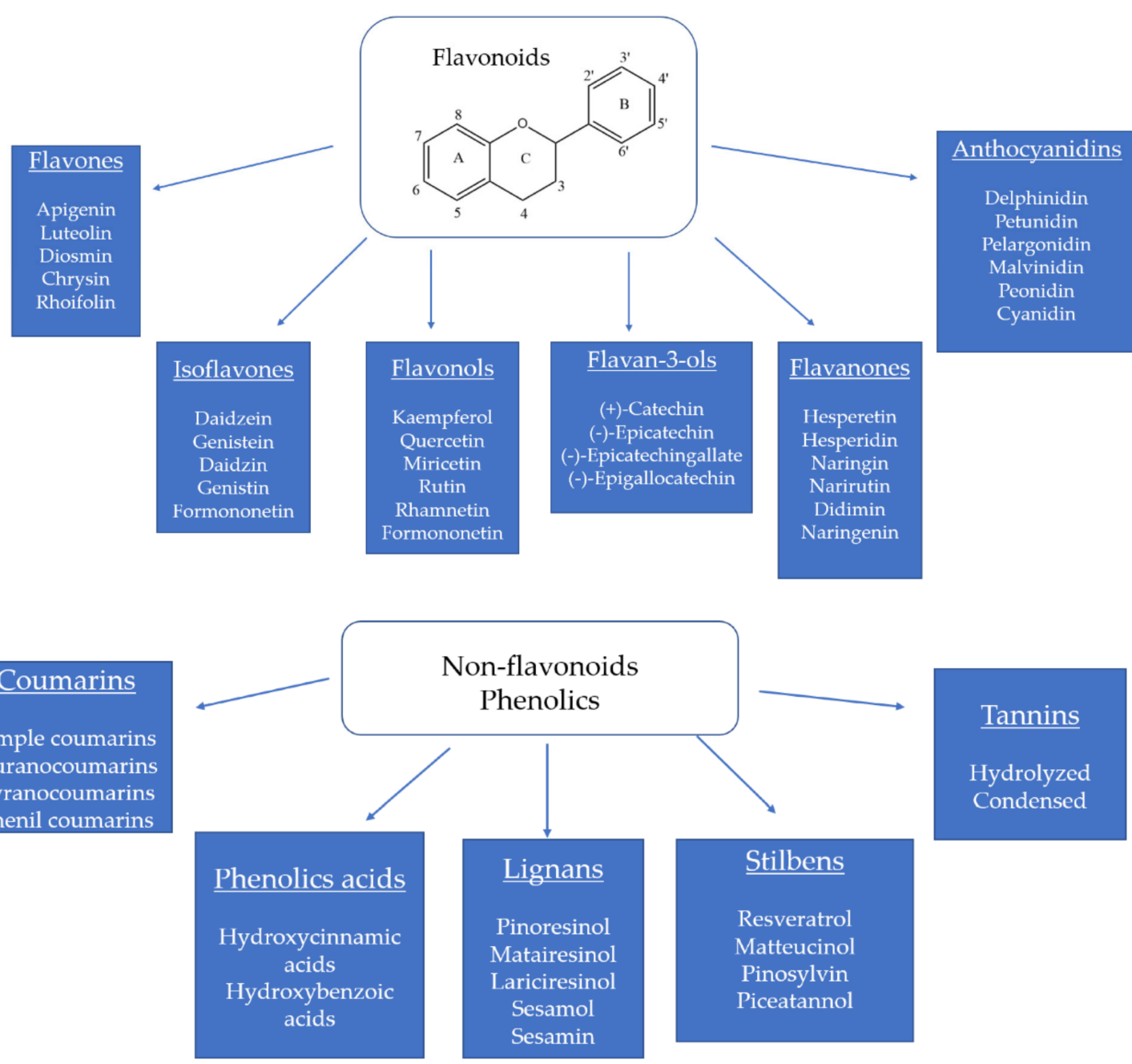

Figure 1. Flavonoid family and non-flavonoid phenolics found in tropical fruits and their coproducts [25-36].

This work reviews the currently available literature concerning flavonoid and nonflavonoid phenolics composition of several tropical fruits and their coproducts, as well 
as the health benefits of their consumption, aiming to provide information for additional studies, as well as to promote the consumption and cultivation of these fruits.

\section{Flavonoids and Non-Flavonoid Phenolics in Tropical Fruits}

Flavonoids and non-flavonoids phenolic compounds are one of the main classes of plant secondary metabolites, with numerous different compounds identified (among them over 8000 flavonoids) [11]. This class of bioactive compound displays a huge variety of structures, including monomeric, dimeric, and polymeric phenols, which are responsible for their bioactive properties [37]. As mentioned previously, the edible and non-edible parts of tropical fruits are an important source of this type of bioactive compound (Figure 2). However, as can be seen throughout this review, it is very difficult to obtain a harmonization of results. This is because each researcher, laboratory or even journal in which the results are published uses a different method of obtaining the extracts, analyzing them and expressing them. Often, when researchers are looking for information about, tropical fruits and their coproducts the number and characteristics of different compounds identified are the same, but in this document we focus on flavonoids that have been quantified and identified in some tropical fruits, so that the reader can see in an easy way which are common. Certainly, this point of view is a new outlook on the relevance and importance of these compounds, along with which are present and in what amount. Regarding this final point, all the values used have been expressed in the same units to express a clearer vision of the composition of this type of bioactive compound.

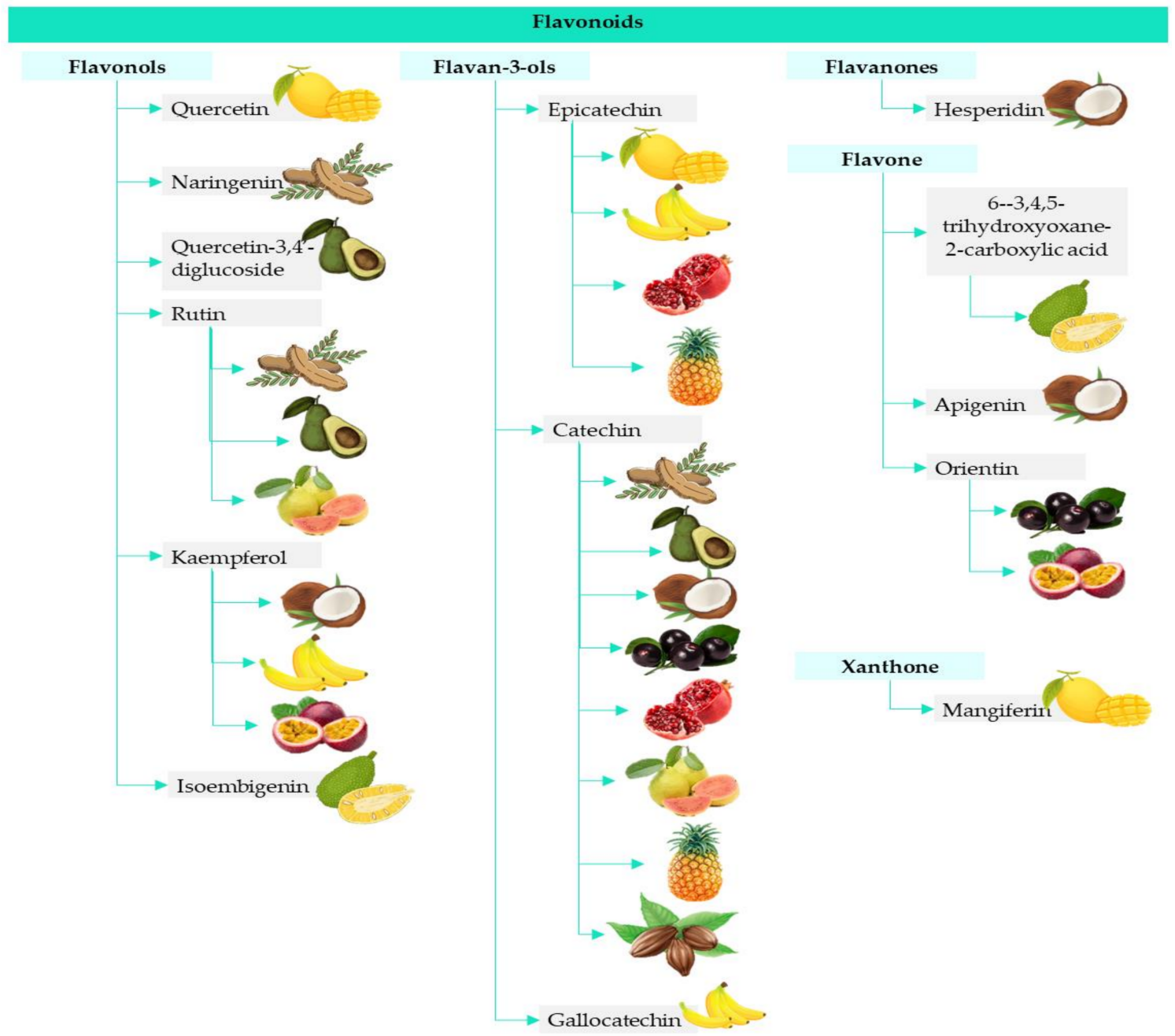

Figure 2. The main flavonoids found in tropical fruits [25-36]. 


\subsection{Açai}

The predominant bioactive constituents of açai fruits (Euterpe oleracea Mart.) are flavonoids, especially anthocyanins, and flavanones. Xiong et al. [25] reported that the principal anthocyanins found in industrially processed açai pulp were cyanindin-3-O-rutinoside (values ranged between 0.29 and $2.18 \mathrm{mg} / \mathrm{g}$ ), cyanindin-3-O-glucoside $(0.31-1.08 \mathrm{mg} / \mathrm{g}$ ), and peonidin-3-O-glucoside (0.04-0.10 mg/g). Previously, Garzón et al. [38] reported that the main flavonoids found in Colombia açais fruits were the flavones orientin $(0.15 \mathrm{mg} / \mathrm{g})$, isovitexin $(0.12 \mathrm{mg} / \mathrm{g})$, homoorientin $(0.10 \mathrm{mg} / \mathrm{g})$ and vitexin $(0.10 \mathrm{mg} / \mathrm{g})$ whilst the principal anthocyanins were cyanidin-3-O-glucoside and cyanidin-3-O-rutinoside. CrespoLópez et al. [39] reported that the main flavonoids found in açai juice were cyanindin-3-Orutinoside $(448.05 \mathrm{mg} / \mathrm{L})$, orientin $(381.02 \mathrm{mg} / \mathrm{L})$ and taxifolin deoxyhexose $(308.00 \mathrm{mg} / \mathrm{L})$. Açaí seeds, a co-product of açai juice extraction, have been reported to have a high content of flavan-3-ols, mainly catechin $(15.67 \mathrm{mg} / \mathrm{g})$, epicatechin $(5.32 \mathrm{mg} / \mathrm{g})$, and their polymers, procyanidins B1 and B2, with values of 16.08 and $1.49 \mathrm{mg} / \mathrm{g}$, respectively [40].

\subsection{Pomegranate}

In pomegranate (Punica granatum L.) it is possible to find numerous types of phytochemicals including flavonoids such as anthocyanins, including cyanidin-3-O-glucoside (22.77 mg/g), cyanidin-3,5-O-diglucoside ( $25.36 \mathrm{mg} / \mathrm{g})$ and pelargonidin-3,5-O-diglucoside $11.16 \mathrm{mg} / \mathrm{g}$ ) [26], flavons and flavonols (kaempferol, luteolin, quercetin, rutin, naringin) and flavan-3-ols (catechin, epicatechin, gallo-catechin) [41], and condensed and hydrolysable tannins including punicalagin with values ranging between 87.8 and $453 \mathrm{mg} / \mathrm{g}$, and punicalin [42] and non-flavonoid phenolics such as ellagic acid, caffeic acid, ferulic acid, chlorogenic acid, and gallic acid, among others [43]. As regards anthocyanin content, this are mainly concentrated in the arils and, therefore, in the juice. In this sense, DíazMula et al. [44] reported that total anthocyanins (Cyanidin-3,5-O-diglucoside, delphinidin3,5-O-diglucoside, pelargonidin-3-O-glucoside, delphinidin-3-glucoside, and cyanidin-3glucoside) content found in arils was $1.63 \mathrm{mg} / \mathrm{g}$, while in pomegranate juice this was $2.03 \mathrm{~g} / \mathrm{L}$. The peel is composed basically of non-flavonoid phenolics. Thus, El-Hadary and Ramadan [14] reported that the main non-flavonoid phenolics identified in pomegranate peel were puicalagin $(98.00 \mathrm{mg} / \mathrm{g})$, followed by ellagic acid $(12.5 \mathrm{mg} / \mathrm{g})$ and gallic acid $(2.50 \mathrm{mg} / \mathrm{g})$.

\subsection{Passion Fruit}

Regarding the flavonoid and non-flavonoid phenolics content of yellow passion fruit (Passiflora edulis Sims f. Flavicarpa), several studies have described the presence of Cglyco-sylflavones as the main flavonoids found in the peel of these fruits, schaftoside, iso-schaftoside, iso-orientin, orientin, isovitexin, vitexin, luteolin-6-C-chinovoside and luteolin-6-C-fucoside, and vicenin-2 being the main constituents [27,45]. On the other hand, in the pulp of passion fruit it is possible to find flavonols and flavan-3-oles. Thus, Carmona-Hernandez et al. [46] reported that (+)-catechin; (-)-epicatechin, and quercetin 3-glucoside were the main constituents of yellow passion fruit lyophilized pulp cultivated in Colombia. A previous study by dos Reis et al. [47] reported that the major flavonoids present in the pulp of yellow passion fruit cultivated in Brazil were quercetin $(5.06 \mathrm{mg} / \mathrm{g})$ and kaempferol $(1.99 \mathrm{mg} / \mathrm{g})$.

\subsection{Guava}

Guava fruit (Psidium guajava L.) contains high amounts of phytochemicals, mainly flavonoids and phenolic acids. Nunes et al. [28] reported that fresh red guava cultivated in Brazil had a high content of the flavonoids rutin and naringenin with values of 0.36 and $0.18 \mathrm{mg} / \mathrm{g}$ dry weight, respectively. In addition, they reported that 2-hydroxybenzoic acid and 3,4-dihydroxyphenylacetic acid were the main non-flavonoid phenolics, with values of 0.11 and $0.22 \mathrm{mg} / \mathrm{g}$, respectively. Lopes dos Santos et al. [48] reported that rutin and catechin, with values of 0.24 and $0.02 \mathrm{mg} / \mathrm{g}$, were the principal flavonoid found in 
white guava, whilst the highest concentrations found for phenolic acids were ellagic acid $(0.15 \mathrm{mg} / \mathrm{g})$, gallic acid $(0.07 \mathrm{mg} / \mathrm{g})$ and vanillic acid $(0.02 \mathrm{mg} / \mathrm{g})$. Da Silva Lima [49] reported that the main flavonoids and non-flavonoid phenolics found in guava pulp were quercetin $(0.19 \mathrm{mg} / \mathrm{g})$, myricetin $(0.11 \mathrm{mg} / \mathrm{g})$, and pinocembrin $(0.11 \mathrm{mg} / \mathrm{g})$, while the principal non-flavonoid phenolics were ellagic acid and gallic acid with values of 7.54 and $4.15 \mathrm{mg} / \mathrm{g}$, respectively. More recently, Tan et al. [50] carried out a study to determine the polyphenolic profile of white and red guava fruits cultivated in China. These authors found that in both white and red guava the main flavonoids were procyanidin B1 $(0.41$ and $0.11 \mathrm{mg} / \mathrm{g}$, respectively) and phloretin $(0.12$ and $0.11 \mathrm{mg} / \mathrm{g}$, respectively). For non-flavonoid compounds, in both white and red guava crypto-chlorogenic acid and chlorogenic acid were predominant, with values of 0.07 and $0.05 \mathrm{mg} / \mathrm{g}$ and 0.04 and $0.08 \mathrm{mg} / \mathrm{g}$, respectively.

\subsection{Pineapple}

Pineapple (Ananas comosus L. Merr.) is a tropical fruit widely cultivated in South America, which may be considered as one of the most valuable fruits for high valueadded compounds due to the fact that, in their composition, is possible to find several bioactive compounds including dietary fiber, organic acids, bromelain, and mainly phenolic compounds and flavonoids. Sun et al. [29] analyzed the polyphenolic profile of 11 pineapple cultivars and found that the pineapple samples analyzed had several flavonoid compounds, among which catechin, with values ranging between 0.05 and $0.28 \mathrm{mg} / \mathrm{g}$ fresh weight, and epicatechin, with values between 0.01 and $0.02 \mathrm{mg} / \mathrm{g}$ fresh weight, were predominant. As regards the non-flavonoid phenolics, sinapinic and chlorogenic acids were the main components. Dominguez et al. [51] reported that the principal flavonoids found in the pulp of pineapple cv Esmeralda were catechin and epicatechin with values of 0.17 and $0.05 \mathrm{mg} / \mathrm{g}$ dry weight, while the main non-flavonoid phenolics were gallic acid $(0.97 \mathrm{mg} / \mathrm{g})$ and vanillic acid $(0.02 \mathrm{mg} / \mathrm{g})$. Similarly, Arampath and Dekker [52] reported that the main flavonoids found in pineapple pulp cultivated in Sri Lanka were catechin and epicatechin with values of 0.64 and $0.38 \mathrm{mg} / \mathrm{g}$ fresh weight.

\subsection{Mango}

Mango (Mangifera indica L.) stands out for its functional value; it generally contains polyphenolic compounds such as mangiferin $(0.26 \mathrm{mg} / \mathrm{g})$, phenolic acids such as sinapic acid $(0.01 \mathrm{mg} / \mathrm{g})$ and gallic acid $(0.02 \mathrm{mg} / \mathrm{g})$, benzophenones and flavonoids such as quercetin $(0.01 \mathrm{mg} / \mathrm{g})[53,54]$. Nevertheless, significant differences in flavonoids and nonflavonoid phenolic compounds between varieties of mango have been reported, and the unripe fruit extract are more abundant in these compounds than ripe fruits [30]. The main phenolic compounds in mango pulp include mangiferin, gallic acid, catechins, quercetin, kaempferol, protocatechuic acid, ellagic acids, propyl and methyl gallate, rhamnetin, and anthocyanins [55]. Mango peel is a rich source of bioactive compounds such as polyphenols. In this way, Nguyen et al. [56] established that mango peel mainly contained galloyl glucoside, mangiferin and quercetin hexoside. Similarly, Sáyago-Ayerdi et al. [57] detected gallo-tannins from 5 (penta-O-galloyl glucose) to 13 galloyl units (trideca-O-galloyl glucose). The flavonoids dominant in mango kernel were mangiferin, homo-mangiferin, isomangiferin, anthocyanins, kaempferol, and quercetin, while gallic, ellagic, 4-caffeoylquinic acids, caffeic, coumaric, protocatechuic, and ferulic are the main non-flavonoid phenolics found in mango kernel [58,59].

\subsection{Avocado}

Avocado (Persea americana Mill.) shows a high content of flavonoid and non-phenolic compounds which can be found in pulp, seed, or peel [60]. Araujo et al. [61] identified 15 major compounds in the peel, such as 11 procyanidins, dimers and trimers in different isomer shapes. Trujillo-Mayol et al. [31] identified that the main flavonoids present in avocado peel were epicatechin $(0.02 \mathrm{mg} / \mathrm{g})$ and hesperidin $(0.01 \mathrm{mg} / \mathrm{g})$. In addition, there 
were non-flavonoid phenolics such as caffeic acid $(0.2 \mathrm{mg} / \mathrm{g})$, coumaric acid $(0.1 \mathrm{mg} / \mathrm{g})$ and ferulic acid $(0.01 \mathrm{mg} / \mathrm{g})$ [62]. The avocado seed has also shown the presence of flavonoids (catechin $1.02 \mathrm{mg} / \mathrm{g}$ dry weight) and other non-flavonoid phenolics including chlorogenic acid, caffeic acid and ferulic acid with values of $0.75,0.22$ and $0.01 \mathrm{mg} / \mathrm{g}$ dry weight, respectively [63]. Other authors reported 11 compounds in avocado seed, tyrosol glucoside $(2.23 \mathrm{mg} / \mathrm{g}), 1$-caffeoylquinic acid $(1.12 \mathrm{mg} / \mathrm{g})$, and hydroxy-tyrosol glucoside $(0.39 \mathrm{mg} / \mathrm{g})$ being the major compounds obtained [64], whereas the avocado pulp contained phenolic compounds such as $p$-coumaric acid glucoside $(0.08 \mathrm{mg} / \mathrm{g}), 5$-feruloylquinic acid $(0.05 \mathrm{mg} / \mathrm{g})$ and $p$-coumaric acid $(0.04 \mathrm{mg} / \mathrm{g})$, among others [60,64].

\subsection{Tamarind}

Tamarind (Tamarindus indica L.) is a fruit rich in phytochemicals, mainly polyphenols, flavonoids, alkaloids, triterpenes and polysaccharides, responsible for the healing properties of the plant $[32,65]$. The presence of polyphenols in tamarind is dominated by pro-anthocyanidin groups such as pro-cyanidin B2, apigenin, catechin, epicatechin, pro-cyanidin dimers, and trimers, eriodyctiol, taxifoline, and naringenin [32,66-68], catechin $(27.00 \mathrm{mg} / \mathrm{g})$, gallic acid $(0.93 \mathrm{mg} / \mathrm{g})$ and naringenin $(0.50 \mathrm{mg} / \mathrm{g})$ being most dominant $[69,70]$. The seed, considered as waste, also has a wide range of flavonoid compounds. It is a rich source of naringenin $(95.30 \mathrm{mg} / \mathrm{g})$, catechin $(54.93 \mathrm{mg} / \mathrm{g})$ and rutine $(15.36 \mathrm{mg} / \mathrm{g})$. It is also possible to find several non-flavonoid phenolics such as gallic acid $(2.14 \mathrm{mg} / \mathrm{g})$, caffeic acid $(4.35 \mathrm{mg} / \mathrm{g})$, and $p$-coumaric acid $(2.09 \mathrm{mg} / \mathrm{g})$ [70].

\subsection{Coconut}

Edible parts and various value-added products of coconut (Cocos nucifera Linn.) contain considerable amount of phenolics, among them flavonoid compounds with biological activity potential. Arivalagan et al. [33] reported the presence of 28 phenolic compounds in coconut tests, including 16 non-flavonoids (phenolic acids) and twelve flavonoids. No-flavonoid compounds were mainly phenolic acids such as trans-cinnamic acid $(1.06 \mathrm{mg} / \mathrm{g})$, protocatechuic acid $(0.87 \mathrm{mg} / \mathrm{g}), p$-coumaric acid $(0.25 \mathrm{mg} / \mathrm{g})$, or $o$ coumaric acid $(0.21 \mathrm{mg} / \mathrm{g})$, among others such as chlorogenic acid, vanillic acid, syringic acid, ferulic acid, caffeic acid, and gallic acid. The flavonoids found were catechin, luteolin, rutin, myricetin, quercetin, naringenin, epicatechin, and epigallocatechin, the main components being apigenin $(0.38 \mathrm{mg} / \mathrm{g})$, hesperidin $(0.43 \mathrm{mg} / \mathrm{g})$, and kaempferol $(3.09 \mathrm{mg} / \mathrm{g})$. Mahayothee et al. [71] determined, in matured coconut meat, the presence of salicylic acid, $p$-hydroxybenzoic acid, syringic acid, m-coumaric acid, $p$-coumaric acid, gallic acid, caffeic acid, and catechin as its main phenolic compounds. Coconut shell fibers also have polyphenolic compounds including gallic acid $(4.30 \mathrm{mg} / \mathrm{g})$, syringic acid $(0.42 \mathrm{mg} / \mathrm{g})$, catechin $(0.49 \mathrm{mg} / \mathrm{g})$, and epicatechin $(0.42 \mathrm{mg} / \mathrm{g})$ [72]. Virgin coconut oil contains non-flavonoid compounds such as phenolic acids; the phenolic acids present are protocatechuic, vanillic, caffeic, syringic, ferulic, and $p$-coumaric acids [73].

\subsection{Cocoa}

Cocoa (Theobroma cacao L.) has been proposed as a rich source of bioactive compounds including flavonoids and non-flavonoid phenolics. The main flavonoid present in all cacao structures is flavan-3-ol. Therefore, Peláez et al. [74] studied the flavonoid profile present in cocoa beans and reported a catechin contents of $0.65 \mathrm{mg} / \mathrm{g}$ for fresh cocoa beans and $0.53,0.27$, and $0.16 \mathrm{mg} / \mathrm{g}$ for beans fermented for 48,96 , and $120 \mathrm{~h}$, respectively. Recently, Urbańska et al. [75] reported that the principal flavonoids found in unroasted cocoa beans were epicatechin $(2.61 \mathrm{mg} / \mathrm{g})$, procyanidin B2 $(1.07 \mathrm{mg} / \mathrm{g})$, and $(+)$-catechin $(0.13 \mathrm{mg} / \mathrm{g})$. Cocoa bean shell, the main co-product from the cocoa industry, is also a great source of bioactive compounds, thus Botella-Martinez et al. [34] reported that catechin and epicatechin were the main flavonoids found in this co-product with values of 4.56 and $6.34 \mathrm{mg} / \mathrm{g}$ dry weight, respectively. Similarly, Hernández-Hernández et al. [76] reported that epicatechin (values ranging between 4.40 and $34.97 \mathrm{mg} / \mathrm{g}$ ) and catechin 
( 0.55 to $3.33 \mathrm{mg} / \mathrm{g}$ ) were the main flavonoids of cocoa bean shells obtained from different genotypes of cacao cultivated in Mexico.

\subsection{Banana}

Banana (Musa paradisiaca L.) has a potential health value because of its chemical content. The peel constitutes approximately $40 \%$ of the weight of the banana and has the highest concentration of flavonoids. Currently, more than 40 polyphenolic compounds have been identified, flavonoids being the most predominant forms, highlighting gallic acid $(3.86 \mathrm{mg} / \mathrm{g})$, catechins, epicatechins $(1.14 \mathrm{mg} / \mathrm{g})$, gallo-catechins $(5.91 \mathrm{mg} / \mathrm{g})$, and anthocyanins [77,78]. Anyasi et al. [35] reported that epicatechin, gallo-catechin and myricetin-3-O-ramnosyl-glycoside are the flavonoids with the highest concentration in ripe bananas.

\subsection{Jackfruit}

Jackfruit (Artocarpus heterophyllus L.) has different structural parts, the peel, pulp, axis, flake, seed coat, and seed kernel [36], but each part of the fruit contains different phenolic compounds. Li et al. [79] found jackfruit axis extract contained principally three phenolics (elenaic acid, Urolithin D, 3-(6-hydroxy-7-methoxy-2H-1,3-benzodioxol-5-yl) prop-2-enoic acid) and one flavonoid (iso-embigenin); Wang et al. [36] found in the leaves of Jackfruit five flavones including artocarpin, cudraflavone $\mathrm{C}$, albanin $\mathrm{A}$, cudraflavone, and brosimone $\mathrm{I}$, two flavanones, norartocarpanone and euchrenone a7, six 2-arylbenzofuran derivatives, moracin $\mathrm{M}$, moracin $\mathrm{C}$, albafuran $\mathrm{B}$, artoindonesianin $\mathrm{B}-1$, demethylmoracin $\mathrm{I}$, and moracin $\mathrm{D}$, one stilbenoid, artocarbene, one lignan, 2,6,2' $6^{\prime}$-tetramethoxy-4,4'-bis(2,3-epoxy-1hydroxy-propyl)biphenyl and one triterpenoid, griffithine A. Likewise, Fang et al. [80] reported, in fruit and roots, three phenolic compounds, namely artocarpesin, norartocarpetin, and oxy-resveratrol.

\subsection{Other Fruits}

Table 1 shows the flavonoid and non-flavonoid phenolics found in different parts of several tropical fruits.

Table 1. Flavonoid and non-flavonoid phenolic compounds found in edible and non-edible parts of several tropical fruits.

\begin{tabular}{|c|c|c|c|c|}
\hline Fruit & Source & Flavonoids & Non-Flavonoids Phenolics & Ref. \\
\hline $\begin{array}{l}\text { Kiwi } \\
\text { (Actinidia arguta (Siebold } \mathcal{E} \\
\text { Zucc.) Planch. ex Miq) }\end{array}$ & Pulp & $\begin{array}{l}\text { Rutin }(0.33 \mathrm{mg} / \mathrm{g} \mathrm{dw}) \text { and } \\
\text { kaempherol-3-O-galactoside } \\
(0.25 \mathrm{mg} / \mathrm{g} \mathrm{dw})\end{array}$ & $\begin{array}{l}\text { Crypto-chlorogenic acid }(0.10 \\
\mathrm{mg} / \mathrm{g} \mathrm{dw}) \text { and neochlorogenic } \\
\text { acid }(0.08 \mathrm{mg} / \mathrm{g} \mathrm{dw})\end{array}$ & [81] \\
\hline $\begin{array}{l}\text { Acerola } \\
\text { (Malpighia emarginata D.C.) }\end{array}$ & Pulp & $\begin{array}{l}\text { Keampferol-3-O-glucoside } \\
(0.33 \mathrm{mg} / \mathrm{g} \mathrm{dw}) \text { and } \\
\text { isorhamnetin }(0.11 \mathrm{mg} / \mathrm{g} \mathrm{dw})\end{array}$ & $p$-coumaric acid $(0.29 \mathrm{mg} / \mathrm{g} \mathrm{dw})$ & [82] \\
\hline $\begin{array}{l}\text { Acerola } \\
\text { (Malpighia emarginata D.C.) }\end{array}$ & Pulp and peel & $\begin{array}{l}\text { Myricetin }(0.94 \mathrm{mg} / \mathrm{g} \mathrm{dw}) \\
\text { and rutin }(0.61 \mathrm{mg} / \mathrm{g} \mathrm{dw})\end{array}$ & $\begin{array}{l}\text { 2,5-dihydroxybenzoic acid } \\
\text { (7.37 mg/g dw) and } \\
\text { 3,4-dihydroxybenzoic acid } \\
(0.98 \mathrm{mg} / \mathrm{g} \mathrm{dw})\end{array}$ & [83] \\
\hline $\begin{array}{l}\text { Jabuticaba } \\
\text { (Myrciaria jaboticaba } \\
\text { (Vell.) O.Berg) }\end{array}$ & Peel & $\begin{array}{l}\text { Cyanidin-3-O-glucoside } \\
(7.25 \mathrm{mg} / \mathrm{g} \mathrm{dw}) \text { and } \\
\text { quercetin-3-O-rutinoside } \\
(1.17 \mathrm{mg} / \mathrm{g} \mathrm{dw})\end{array}$ & $\begin{array}{l}\text { Ellagic acid }(0.23 \mathrm{mg} / \mathrm{g} \mathrm{dw}) \text { and } \\
\text { gallic acid }(0.13 \mathrm{mg} / \mathrm{g} \mathrm{dw})\end{array}$ & [84] \\
\hline $\begin{array}{l}\text { Jabuticaba } \\
\text { (Myrciaria jaboticaba } \\
\text { (Vell.) O.Berg) }\end{array}$ & Seeds & $\begin{array}{l}\text { Castalagin }(0.13 \mathrm{mg} / \mathrm{g} \mathrm{dw}) \\
\text { and vescalagin }(0.69 \mathrm{mg} / \mathrm{g} \mathrm{dw})\end{array}$ & $\begin{array}{l}\text { Ellagic acid }(3.80 \mathrm{mg} / \mathrm{g} \mathrm{dw}) \text { and } \\
\text { gallic acid }(2.30 \mathrm{mg} / \mathrm{g} \mathrm{dw})\end{array}$ & [85] \\
\hline $\begin{array}{l}\text { Rambutan } \\
\text { (Nephelium lappaceum L.) }\end{array}$ & Seeds & $\begin{array}{l}\text { Geraniin }(0.42 \mathrm{mg} / \mathrm{g} \mathrm{dw}) \text { and } \\
\text { corilagin }(0.09 \mathrm{mg} / \mathrm{g} \mathrm{dw})\end{array}$ & $\begin{array}{l}\text { Ellagic acid }(0.46 \mathrm{mg} / \mathrm{g} \mathrm{dw}) \text { and } \\
\text { gallic }(0.10 \mathrm{mg} / \mathrm{g} \mathrm{dw})\end{array}$ & [86] \\
\hline
\end{tabular}


Table 1. Cont.

\begin{tabular}{|c|c|c|c|c|}
\hline Fruit & Source & Flavonoids & Non-Flavonoids Phenolics & Ref. \\
\hline $\begin{array}{l}\text { Lychee } \\
\text { (Litchi chinensis Sonn) }\end{array}$ & Seeds & $\begin{array}{l}\text { Rutin }(0.098 \mathrm{mg} / 100 \mathrm{~g} \mathrm{dw}) \text { and } \\
\text { scopoletin }(0.076 \mathrm{mg} / 100 \mathrm{~g} \mathrm{dw})\end{array}$ & N.D. & [87] \\
\hline $\begin{array}{l}\text { Dragon fruit } \\
\text { (Hylocereus spp.) }\end{array}$ & Pulp & $\begin{array}{l}\text { Myricetin }(0.18 \mathrm{mg} / \mathrm{g} \mathrm{dw}) \\
\text { and quercetin }(0.06 \mathrm{mg} / \mathrm{g} \mathrm{dw})\end{array}$ & Gallic acid $(0.23 \mathrm{mg} / \mathrm{g} \mathrm{dw})$ & [88] \\
\hline $\begin{array}{l}\text { Kaki } \\
\text { (Dyospiros kaki L.) }\end{array}$ & Pulp & $\begin{array}{l}\text { Epicatechin }(0.03 \mathrm{mg} / \mathrm{g} \mathrm{dw}) \\
\text { and catechin }(0.02 \mathrm{mg} / \mathrm{g} \mathrm{dw})\end{array}$ & Gallic acid (2.96 mg/g dw) & [89] \\
\hline $\begin{array}{l}\text { Longan } \\
\text { (Dimocarpus longan Lour) }\end{array}$ & Peel & Corilagin (2.15 mg/g dw) & $\begin{array}{l}\text { Ellagic acid }(0.08 \mathrm{mg} / \mathrm{g} \mathrm{dw}) \text { and } \\
\text { gallic acid }(0.18 \mathrm{mg} / \mathrm{g} \mathrm{dw})\end{array}$ & [90] \\
\hline $\begin{array}{l}\text { Longan } \\
\text { (Dimocarpus longan Lour) }\end{array}$ & $\begin{array}{l}\text { Seed } \\
\text { coat }\end{array}$ & Corilagin $(5.53 \mathrm{mg} / \mathrm{g} \mathrm{dw})$ & $\begin{array}{l}\text { Ellagic acid }(0.83 \mathrm{mg} / \mathrm{g} \mathrm{dw}) \text { and } \\
\text { gallic }(0.49 \mathrm{mg} / \mathrm{g} \mathrm{dw})\end{array}$ & [91] \\
\hline $\begin{array}{l}\text { Camu-camu } \\
\text { (Myrciaria dubia McVaugh) }\end{array}$ & Seed coat & Rutin $(0.13 \mathrm{mg} / \mathrm{g} \mathrm{dw})$ & $\begin{array}{l}\text { Ferulic acid }(0.59 \mathrm{mg} / \mathrm{g} \mathrm{dw}) \text { and } \\
p \text {-coumaric acid }(0.49 \mathrm{mg} / \mathrm{g} \mathrm{dw})\end{array}$ & [92] \\
\hline $\begin{array}{l}\text { Camu-camu } \\
\text { (Myrciaria dubia McVaugh) }\end{array}$ & Pulp & $\begin{array}{l}\text { Catechin }(0.12 \mathrm{mg} / \mathrm{g} \mathrm{dw}) \text { and } \\
\text { myricetin }(0.02 \mathrm{mg} / \mathrm{g} \mathrm{dw})\end{array}$ & $\begin{array}{l}\text { Ellagic acid }(0.19 \mathrm{mg} / \mathrm{g} \mathrm{dw}) \text { and } \\
\text { syringic acid }(0.07 \mathrm{mg} / \mathrm{g} \mathrm{dw})\end{array}$ & [93] \\
\hline $\begin{array}{l}\text { Noni } \\
\text { (Morinda citrifolia L.) }\end{array}$ & Pulp & $\begin{array}{l}\text { Catechin }(1.11 \mathrm{mg} / \mathrm{g} \mathrm{dw}) \text {, } \\
\text { rutin }(0.40 \mathrm{mg} / \mathrm{g} \mathrm{dw}) \text { and } \\
\text { quercetin }(0.27 \mathrm{mg} / \mathrm{g} \mathrm{dw})\end{array}$ & Gallic acid $(0.24 \mathrm{mg} / \mathrm{g} \mathrm{dw})$ & [94] \\
\hline $\begin{array}{l}\text { Noni } \\
\text { (Morinda citrifolia L.) }\end{array}$ & Pulp & $\begin{array}{l}\text { Scopoletin }(0.53 \mathrm{mg} / \mathrm{g} \mathrm{dw}) \\
\text { and rutin }(0.54 \mathrm{mg} / \mathrm{g} \mathrm{dw})\end{array}$ & N.D. & {$[95]$} \\
\hline
\end{tabular}

N.D.: No determined; dw: dry weight.

\section{Biological Effects}

Tropical fruit consumption has demonstrated numerous beneficial health effects (Table 2) which are related to the high content of bioactive compounds present in these fruits. Beneficial health properties of bioactive compounds include antioxidant, antiproliferative, anti-inflammatory, neuroprotective, antihypertensive, hypo-cholesterolemic, and hypoglycemic properties $[17,66,70,80]$. These beneficial effects can be used to prevent several diseases including cardiovascular, cancer, and diabetes mellitus diseases as well as neurodegenerative diseases [96-121]. Table 2 shows several biological effects of flavonoids and non-flavonoid phenolics present in tropical fruits. These theoretical approaches and hypotheses on the potential role of plant secondary metabolites such as flavonoids and nonflavonoids phenolics against several diseases seem to be reasonable, as most of them have been justified so far, either with in vitro or in vivo studies or by different interventional clinical trials in humans.

From our point of view, a greater number of studies with humans has to be carried out to ensure, in a conclusive way, all the potential benefits provided by the consumption of fruits in general and tropical fruits in particular, which provide a large number of bioactive compounds. 
Table 2. Beneficial health effects of flavonoid and non-flavonoid phenolic compounds found in edible and non-edible parts of several tropical fruits.

\begin{tabular}{|c|c|c|c|}
\hline Polyphenolic Compound & Biological Activity & Mechanism & Ref. \\
\hline \multicolumn{4}{|l|}{ Tannin } \\
\hline Punicalagin & Anticancer & $\begin{array}{l}\text { Inhibition of the invasion, migration, and viability of } \\
\text { breast cancer cells. Decreases the expression of } \\
\text { N-Cadherin, Golgi phosphoprotein 3, matrix } \\
\text { metalloproteinase-2, matrix metalloproteinase-9 }\end{array}$ & [97] \\
\hline
\end{tabular}

\section{Flavonols}

Anti-inflammatory

Quercetin-3-O-glucuronide

Antidiabetic

Quercetin Photoprotective

Naringenin Antioxidative
Decreases in ROS-associated inflammation by inhibition of interleukin- 6 and tumor necrosis factor- $\alpha$ production with suppression of IKK $\beta$ /NF-kB phosphorylation. Facilitates the PI3K signaling by positive regulation of serine/tyrosine phosphorylation of insulin receptor substrate-1 (IRS-1).

Absorbs UV radiation, inhibits UV-induced inflammation in primary keratinocytes, and inhibits skin damage produced by UVB rays.

Protects ocular neurons from degeneration, reverses retinal pigment epithelium degeneration and laser-induced choroidal neovascularization

\section{Flavone}

Artocarpesin

Anti-inflammatory

Baicalein

Antifungal

Suppresses the LPS-induced production of nitric oxide (NO) and prostaglandin E2

Inhibition of outflow pumps, since they decreased their efficiency, which eventually led to cell death or apoptosis.

\section{Flavan-3-ols}

Benzo-tropolona

$\begin{array}{lc} & \begin{array}{c}\text { Antioxidant } \\ \text { Antiangiogenic }\end{array} \\ \text { Catechin } & \text { Antidiabetic } \\ \text { and procyanidins } & \text { Antitumor } \\ \text { and epicatechin } & \text { Antioxidant }\end{array}$

Epicatechin

Antiproliferative capacity

Anti-inflammatory

Gallo-catechin
Anticancer

Antioxidant
Reduces the viability of human breast (MCF7), lung (H1299), colon (HT29), and prostate (LNCaP) cancer cells in vitro. After $12 \mathrm{~h}$ treatment on a model in vivo the G0/G1 phase cell cycle arrests in LNCaP cells.

Reduces lipid hydroperoxide formation in an oil-in-water emulsion $(33 \%$ reduction at $500 \mu \mathrm{g} / \mathrm{mL})$.

Inhibition of kinase proteins.

Protective effect on pancreatic $\beta$ cells Increased glucose absorption. Reduces the blood glucose level.

Inhibitory effect against cervical carcinoma cell

Stabilizes peroxyl radicals, superoxide radical and hypochlorous reactive species.

Immunosuppressive effect on $\mathrm{T}$ cell proliferation

Prevention of oxysterol mixture-induced InterLeukin-8

release (pro-inflammatory cytokine) $\mathrm{DPPH}$ radical scavenging activity

\section{Anthocyanins}

Cyanidin glycosides

Anticancer

Decreases the total number of aberrant crypt foci, aberrant crypt foci multiplicity, tumor cell proliferation and incidence of tumors with high grade dysplasia

Pro-anthocyanins
Resveratrol
Cardioprotective
Anti-obesity
Antioxidant

Effects via nitric oxide release, Nrf2 pathway, and antioxidant activity.

Reduction of lipid accumulation in a dose dependent-manner. Hypolipidemic activity. Scavenges radicals and inhibits xanthine oxidase. 
Table 2. Cont

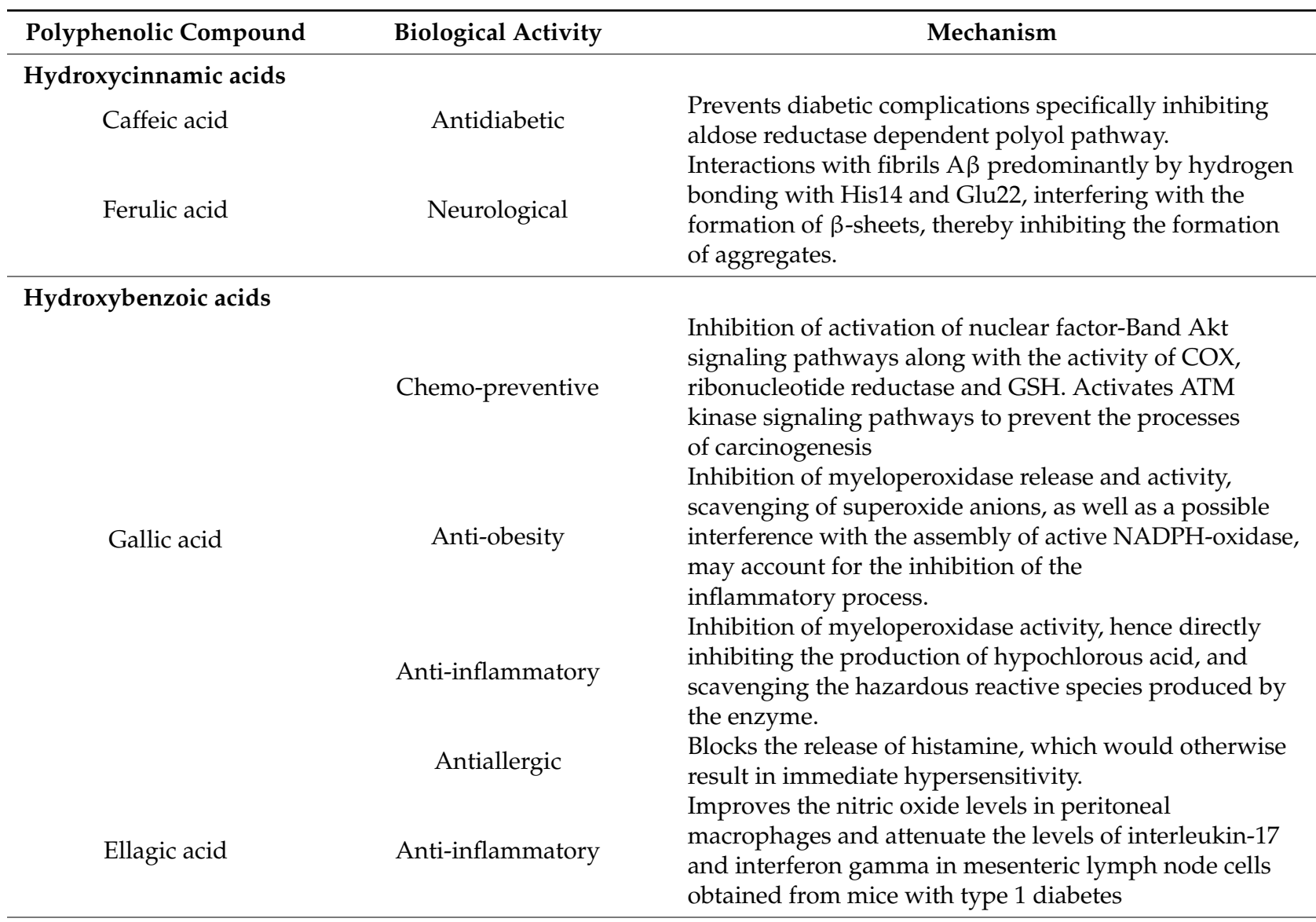

Ref. formation of $\beta$-sheets, thereby inhibiting the formation

Inhibition of activation of nuclear factor-Band Akt signaling pathways along with the activity of COX ribonucleotide reductase and GSH. Activates ATM of carcinogenesis

Inhibition of myeloperoxidase release and activity, interference with the assembly of active NADPH-oxidase, Inhibition of myeloperoxidase activity, hence directly inhibiting the production of hypochlorous acid, and scavenging the hazardous reactive species produced by

Xanthone

Chemo-preventive

Neuroprotective

Mangiferin

Cardioprotective

Anti-inflammatory

Antidiabetic
Decreases in the cell cycle by reducing proliferation, metastasis and promoting apoptosis of malignant cells. Up-regulates dopamine concentrations and diminishes neurotoxin's effects which involve oxidative stress, mitochondrial dysfunction, and apoptosis.

Improved object recognition memory in healthy rats through a mechanism that might involve an increase in neurotrophin and cytokine levels. Increases the concentration of phospholipids in cardiac tissue and restore the activity of antioxidant enzymes: superoxide dismutase, catalase, glutathione peroxidase, glutathione transferase and glutathione reductase. Inhibits the enzyme phospholipase A2, in human synovial secretion, and suppresses the release of inflammatory mediators prostaglandin $\mathrm{E}_{2}$ and leukotriene B4 by macrophages.

Reduction of hyperglycemia and atherogenicity in diabetic rats through a significant decrease in blood glucose levels as well as a decrease in serum concentrations of triglycerides, total cholesterol and low-density lipoprotein cholesterol.

\subsection{Açai}

Açai (Euterpe oleracea Mart.) is a berry-like fruit native to the Amazon region which has recently gained popularity in North America and Europe due to its bioactivity demonstrated in in vitro and in vivo studies, including anti-inflammatory, antioxidant, antimicrobial, antinociceptive, anticancer, anti-atherogenic, and healing activities [122,123]. Several 
of these compounds have been associated with preventing the development of several chronic diseases. For instance, some research studies have been published reporting the consumption of açai berries, açai juice or açai extracts with the potential to prevent dyslipidemia, or as chemoprotective agents against cancer [107,124-126]. In this respect, the effect on the blood lipid profile of consumption of $200 \mathrm{~mL} /$ day of açaí juice during four weeks with a 4-week washout period was analyzed by de Liz et al., [124]. These authors reported that, after four weeks, açaí juice increased the concentrations of high-density lipoprotein cholesterol by $7.7 \%$. Additionally, açaí juice intake improved the oxidative stress biomarkers significantly, and increase in total antioxidant capacity, catalase, and glutathione peroxidase by $66.7 \%, 275.1 \%$, and $15.3 \%$, respectively, while the oxidative stress index decrease was 55.7\% compared to baseline. Previously, Pala et al., [126] reported that açaí pulp consumption ( $0.2 \mathrm{~kg} /$ day for 28 days) had no effect on blood lipid profile parameters of healthy women. However, açaí pulp intake increased the serum levels of apolipoprotein A1 and the activity of paraoxonase-1, whose molecules are high-density lipoprotein cholesterol precursors.

Another very important health property of açai fruit berry is its anti-cancerogenic activity. Therefore, some studies have inquired about the antitumoral properties of açai. For example, Barros et al. [102] analyzed the cytotoxicity of açai seeds extract against several tumor cell lines including MCF-7 (breast adenocarcinoma), NCI-H460 (non-small cell lung cancer), HeLa (cervical carcinoma) and HepG2 (hepatocellular carcinoma). According to the authors, açaí seeds extract, with a high content of flavan-3-ols (i.e., catechins and procyanidins), had an inhibitory effect against tumor cell lines assayed, being more effective for the cervical carcinoma cell line with a GI50 of $18 \mu \mathrm{g} / \mathrm{mL}$. Choi et al. [127] reported that the consumption of açai berries (pellets containing $5 \%$ ) decreased the incidence of both adenoma (from $76.9 \%$ to $23.1 \%$ ) and cancer (from $76.9 \%$ to $15.4 \%$ ), as well as the expression of proinflammatory cytokines, including tumor necrosis factor $\alpha$, interleukin- $1 \beta$ and interleukin-6, in colorectal cancer. Fragoso et al. [107] carried out a study to assess the potential protective effects of açaí pulp in a colitis-associated carcinogenesis rat model. These authors found that ingestion of lyophilized açai pulp with a high concentration of anthocyanins (mainly cyanidin glycosides) decreases the total number of aberrant crypt foci, aberrant crypt foci multiplicity, tumor cell proliferation and incidence of tumors with high-grade dysplasia. In addition, açai pulp enhanced the gene expression of negative regulators of cell proliferation, as well as inflammation. In the same way, Martins et al. [128] found that the viability of the human lung carcinoma cell line (A549) decreases (72.07\%) with açai extract $(200 \mu \mathrm{g} / \mathrm{mL})$ treatment after $48 \mathrm{~h}$. In addition, açai extracts increased the percentage of cells in the G0/G1 phase and promoted a high growth of apoptotic cells, compared with non-treated cells.

\subsection{Pomegranate}

Pomegranate (Punica granatum L.) fruits are consumed worldwide, fresh, or processed in the form of juice, jam, wine, oil obtained from seeds and in extract supplements [129]. In the composition of both peel and arils, it is possible to find numerous types of phytochemical including flavonoids and non-flavonoid phenolics. Due to this high content of these bioactive compounds an extensive range of health benefits have been attributed, including anti-inflammatory, antioxidant, antibacterial, and antiviral properties, as well as playing a role in lipid regulation and immunomodulation [41,130,131].

As mentioned above, pomegranate and pomegranate derivates have demonstrated several health benefits. In this sense, Sohrab et al. [132] carried out a study to investigate the effects of pomegranate juice consumption ( $200 \mathrm{~mL} /$ day for 6 weeks) on the blood lipid profile of healthy volunteers. These authors reported that, at the conclusion of the intervention, total cholesterol, total triglycerides, low-density lipoprotein cholesterol and high-density lipoprotein cholesterol did not show any change between the intervention group and the control group, but total cholesterol and low-density lipoprotein cholesterol decreased significantly compared to pre-trial values within the intervention group. 
El-Hadary and Ramadan [14] conducted a study to analyze the oral administration of pomegranate extract at $200 \mathrm{mg} / \mathrm{kg}$ for 56 days on hyperlipidemic rats. According to the authors significantly lower values were achieved for total lipid, total cholesterol, low-density lipoprotein cholesterol and very low-density lipoprotein cholesterol, while high-density lipoprotein cholesterol levels increased. In a similar study, Grabež et al. [130] evaluated the effects of pomegranate peel extract consumption on plasma lipid profile and fatty acid level in patients with diabetes mellitus type 2 . These authors reported that plasma levels of triglycerides, low-density lipoprotein cholesterol/high-density lipoprotein cholesterol ratio, and $\mathrm{HbA1c}$ were significantly reduced, whilst the level of high-density lipoprotein cholesterol was augmented, compared to placebo intake.

In reference to the preventive effects of pomegranate on carcinogenesis, Pan et al. [96] investigated the effect of punicalagin, one of the most important bioactive compounds found in pomegranate, on the cellular process in breast cancer and its molecular mechanism. These authors found that a high dose of punicalagin ( $50 \mu \mathrm{M}$ or higher) inhibited the invasion potential, migration, and viability of breast cancer cells. In addition, the expression of N-Cadherin, Golgi phosphoprotein 3, matrix metalloproteinase-2, and matrix metalloproteinase-9 decreased. Similarly, Nasser et al. [133] investigated the antitumor effect of pomegranate juice on human lung adenocarcinoma basal epithelial cells (A549). These authors reported that the treatment of A549 cells with pomegranate juice, which had a high content in flavonoids and non-flavonoid phenolic compounds, produced a decrease in the viability of these cells in a concentration-dependent manner. Thus, for lyophilized pomegranate juice concentrations of 300 and $600 \mu \mathrm{g} / \mathrm{mL}$ a reduction of $26 \%$ and $49 \%$ of cell viability, respectively, was achieved.

Another interesting property of pomegranates is their anti-inflammatory activity. Therefore, the anti-inflammatory activity of pomegranate extracts, or pomegranate juice had been described by numerous in vitro and in vivo studies. Karwasra et al. [134] analyzed the anti-inflammatory activity of pomegranate rind extracts. They reported that pomegranate extracts at $200 \mathrm{mg} / \mathrm{kg}$ reduced pain and inflammation by downregulating the activation of tumor necrosis factor R1, tumor necrosis factor alpha, interleukin- $1 \beta$, interleukin-6, nuclear factor- $\mathrm{kB}$, oxidative stress markers, and tissue histology. In a previous study, Stojanović et al. [135] reported that a pomegranate peel extract rich in punicalin, punicalagin, and ellagic acid improved the nitric oxide levels in peritoneal macrophages and attenuated the levels of interleukin-17 and interferon-gamma in mesenteric lymph node cells obtained from mice with type 1 diabetes.

\subsection{Passion Fruit}

The fruits of the genus Passiflora showed a high content of bioactive compounds, mainly polyphenolic compounds, which have demonstrated several health benefits such as anti-inflammatory activity, anti-cancerogenic properties, and the prevention of cardiovascular diseases [136,137]. Regarding the latter, Barbalho et al. [136] studied the daily ingestion of passion fruit juice on the biochemical profile of diabetic rats. These authors found that, at the end of the study (30 days), the rats showed significantly reduced total cholesterol, triglyceride, and low-density lipoprotein cholesterol levels, and an increased high-density lipoprotein cholesterol level. Fernandes Marques et al. [138] analyzed the effects of daily ingestion of passion fruit peel flour in patients with HIV. The authors reported that, at the end of the study (90 days), this ( $30 \mathrm{~g})$ was effective in reducing total cholesterol $(15.1 \%$ with respect to the initial value) and triglycerides ( $16.1 \%$ with respect to the initial value) after 30 days. The concentrations of low-density lipoprotein cholesterol decreased by $12.7 \%$ with respect to initial values, while high-density lipoprotein cholesterol increased by $13.4 \%$ with respect to the initial value.

Another important property of Passiflora spp. is its anti-cancer activities. Thus, Ballesteros-Vivas [137] analyzed the anti-proliferative potential of Passiflora mollissima Bailey against HT-29 colon cancer cells. These authors reported that, after treatment for 48 and $72 \mathrm{~h}$, the viability of HT-29 colon cancer cells was evidently affected, while low effects 
were obtained on normal human colon fibroblast cells. The bioactive extract was shown to block HT-29 cells in the S and G2/M phases of the cell cycle, which could be facilitated by the inactivation of the FAT10 cancer signaling pathway. Kasala et al. [139] analyzed the anticancer effect of chrysin, a flavonoid found in fruits of the Passiflora genus. The authors reported that chrysin treatment $(250 \mathrm{mg} / \mathrm{kg}$ body weight) in mice significantly reduces the benzo(a)pyrene-induced lung carcinogens. Thus, chrysin supplementation downregulated the expression of proliferating cell nuclear antigen, cyclooxygenase-2 and nuclear factor- $\mathrm{\kappa} \mathrm{B}$, where these proteins maintained cellular homeostasis.

\subsection{Guava}

Guava (Psidium guajava L.) is a popular fruit of tropical and subtropical countries. In its composition, it is possible to find several bioactive compounds These bioactive nutrients play significant roles in several health problems related to lifestyle diseases, such as diabetes (type 2), cardiovascular disease, several cancer types and obesity. As regards the hypocholesterolemic properties of guava, Maryanto and Marsono, [140] carried out a study to assess the potential of red guava in reducing cholesterol content in hyper-cholesterolemic rats. They found that red guava intake significantly reduced the contents of total cholesterol (32\%), low-density lipoprotein cholesterol (43\%), and triglyceride (18\%). On the other hand, red guava intake significantly increased high-density lipoprotein cholesterol content $(18 \%)$. Shabbir et al. [141] mentioned that diet supplementation with polyphenols, obtained from guava pulp, significantly increased the level of high-density lipoprotein in groups fed with polyphenols compared to control groups. Additionally, total cholesterol and low-density lipoprotein levels were significantly decreased.

Another very important health-related property of guava is its anticarcinogenic activity. Therefore, Feng et al. [142] analyzed the cytotoxic activities of several flavonoids (guavinosides and quercetin glycosides) obtained from ethanolic extract of guava fruits. These authors reported that the guavinosides and quercetin glycosides inhibited the cell proliferation from gastric carcinoma cells SGC-790, A-549, and HeLa cells. Recently, in an interesting study, Correa et al. [143] evaluated the anticarcinogenic potential of three guava cultivar fruit pulp extracts in MDA-MB-435 and MCF-7 human breast cancer cells. The author reported that, after $48 \mathrm{~h}$ of treatment, all the guava cultivars' extracts caused reduction of MDA-MB-435 and MCF-7 cell viability. Additionally, all guava extracts caused MDA-MB-435 and MCF-7 cell count reduction in G0/G1 and G2/M phases and increased apoptosis. Guava fruits also showed anti-inflammatory properties. Thus, Li et al. [144] reported that the expression of inflammatory proteins, such as iNOS and NF- $\mathrm{B}$, was suppressed via activated PPAR $\gamma$, and the expression levels of GPx3 and ACO increased in rats fed with guava fruit for 8 weeks.

\subsection{Pineapple}

Pineapple (Ananas comosus L. Merr), based on the content of its bioactive compounds, could be considered a fruit with a high number of health benefits. Thus, Saxena and Panjwani [145] reported that treating rats with hydroalcoholic extract of pineapple (200-400 mg/kg/day, oral) for a period of 30 days reduced the values of cholesterol, low-density lipoprotein, very low-density lipoprotein and triglycerides, whilst it increased high-density lipoprotein and total protein levels. Similarly, Seenak et al. [146] reported that daily pineapple ingestion reduced serum lipid profiles, atherogenic coefficient, cardiac risk ratio, and liver enzyme activity. Additionally, daily ingestion of pineapple also restored cardiac protein carbonyl content, and decreased the cardiac malondialdehyde and the cardiac pro-inflammation cytokine Interleukin-6 and Interleukin-1 $\beta$ levels.

\subsection{Mango}

Mango (Mangifera indica L.) is the world's most commonly produced tropical fruit, and is originally from Asia [147,148]. As mentioned above, this fruit showed multiple biological effects due to its high content of bioactive compounds. Therefore, the most active biological 
constituent of mango is the xanthone known as mangiferin, with biological properties such as antiviral, anticancer, antidiabetic, antioxidative, antiaging, immunomodulatory, hepatoprotective and analgesic effects, and also as a promising therapeutic agent against neurodegenerative disorders [116,149].

Flavonoids and non-flavonoid phenolics present in mango have multiple biological effects. These phytochemicals have shown high antioxidant, nutraceutical, antimicrobial, anticancer, and pharmaceutical significance and antiproliferative activities [59]. Worth noting mangiferin, as one of the major compounds in mango, may be a compound with high cancer chemo-preventive potential and possible preventive effect against oncogenesis [150]. In this sense, Gold-Smith et al. [115] confirmed that mangiferin causes a decrease in the cell cycle by detecting an abnormal alteration, thereby reducing proliferation, metastasis and promoting apoptosis of malignant cells.

Potential health benefits have also been studies, including antibiotic capacity, prebiotic effects, and their effect in non-communicable chronic diseases such as obesity, diabetes mellitus, cancer, cardiovascular, neurological, and inflammatory diseases [151].

\subsection{Avocado}

Avocado (Persea americana Mill.) is an important native fruit of Mexico and Central America, cultivated in tropical and subtropical regions of the world. This fruit is also considered very valuable because it has a complete nutritional content associated with many health benefits due to the high levels of unsaturated fatty acids, minerals, fiber, proteins, vitamins and phenolic compounds [102,152]. This high content of phenolic compounds confers to avocado numerous biological activities, including antifungal, antibacterial, antidiabetic, antihypertensive, anti-inflammatory, anticancer, and hypo-cholesterolemic properties [31,61,103,153,154]. Ervianingsih et al. [155] used avocado seed waste in biscuits as an alternative food for people with diabetes, because studies demonstrated that the flavonoids could reduce blood glucose levels through glucose absorption or by increasing insulin secretion, can stimulate glucose absorption in peripheral tissues, and regulate the work of enzymes involved in carbohydrate metabolic pathways.

Tremocoldi et al. [103] determined that epicatechin and catechin had antioxidant activity since they can stabilize peroxyl radicals, superoxide radical and hypochlorous reactive species. Likewise, Dabas et al. [17] found that avocado seed extract has antioxidant capacity and significant bioactivity in reducing cell viability and inducing apoptosis in human prostate, colon, lung and human breast cancer cells. The presence of hydroxycinnamic acid derivatives in avocado has an important antioxidant effect and anti-inflammatory properties. Alam et al. [156] suggest that these compounds may enhance cardiovascular health by exerting blood pressure-lowering effects and by acutely improving the endothelial function. There is also an effect on adipose tissues, inhibiting macrophage infiltration and nuclear factor $\mathrm{kB}(\mathrm{NF}-\mathrm{kB})$ activation in obese animals.

The presence of procyanidins in avocado has been involved in different beneficial effects. Eldaim et al. [157] reported that procyanidins mitigate DNA damage in tumoral kidneys through a mechanism that involves P53 ANDPCNA proteins expression, and normalize serum levels of urea, creatinine, potassium, and chloride. Enayati et al. [108] found, in an in vivo model, that procyanidins exert cardioprotective effects through a mechanism mediated via the release of nitric oxide, increasing the antioxidant activity and scavenging of reactive oxygen species. Likewise, the procyanidins have a potentiating effect, both in vitro and in vivo, on a broad range of antibiotic classes against pathogenic Escherichia coli, Proteus mirabilis, and Pseudomonas aeruginosa. Evidence that this acts by repressing two antibiotic resistance mechanisms, selective membrane permeability, and multidrug efflux pumps, has been presented [158,159].

Other studies show that catechin compounds quercetin, and hesperidin, among other flavonoids, have the potential to be used in the design of coadjutant therapies against viral infection [160]. Russo et al. [161] found flavonoids such as quercetin, baicalin, luteolin, hesperetin, gallo-catechin gallate, and epigallocatechin gallate interfere with the replication 
cycle of the coronavirus in vitro, therefore flavonoids and their derivative may represent target compounds to be tested in future clinical trials to enrich the drug arsenal against coronavirus infections. Wu et al. [162] reported that avocado extract can inhibit dengue virus replication via regulation of NF- $\mathrm{kB}$-dependent induction of the antiviral interferon response. Finally, avocados do not contain potentially toxic or harmful compounds, making them a promising natural source of bioactive compounds for many applications in the food and pharmaceutical industries.

\subsection{Tamarind}

Tamarindus indica L., commonly known as tamarind, is a tropical fruit from Africa, India, and Thailand that belongs to the subfamily Caesalpinioideae of the family Leguminosae (Fabaceae) [32]. It is generally consumed fresh for its attractive bittersweet flavour and sometimes dried or ground in products such as juices, syrup, pulps, dehydrated fruits, gelatin, and sweet products $[163,164]$. Tamarind leaves, pulp, seeds, veins, and skins are sources of bioactive compounds with antioxidant, hypolipidemic, antihyperglycemic, antimicrobial, anti-inflammatory, analgesic, hepatogenic, antihypertensive, and spasmolytic properties [66,68,69,163-165]. The seed, considered as waste, also has a wide range of biological effects. This coproduct showed antioxidant capacity due to the inhibition of enzymes such as aldose, reductase, ATPase, lipoxygenase, and cyclooxygenase enzymes responsible for the generation of cytotoxic free radicals [166].

In an in vitro study conducted by Bhadoriya et al. [101], it was reported that consumption of tamarind seed extract $(100 \mathrm{mg} / \mathrm{kg}$ at $250 \mathrm{mg} / \mathrm{kg})$ may have a protective effect on pancreatic $\beta$-cells, increased glucose uptake, and decreased body weight, along with recovery of altered hematological parameters.

\subsection{Coconut}

The phenolic compounds of coconut (Cocos nucifera Linn.) have other health benefits. For example, the presence of flavonoids (quercetin and catechin) in the ethanolic extract of coconut husk fiber has photoprotective action. In addition, it contains antioxidant and antiglycation properties that can reduce the effects of oxidative damage caused by ultraviolet radiation, offering stability to sunscreens and assisting in the preservation of collagen [77]. Another biological activity of coconut is its implication in the prevention of microvascular diabetic complications. Sheela et al. [109] in an in silico analysis, reported that a coconut extract reduced the expression of aldose reductase, an enzyme implicated in the activation of the polyol pathway, responsible for triggering diabetic complications. A study carried out by Nikooei et al. [167] found that intake of $30 \mathrm{~mL}$ of virgin coconut oil, for four weeks in subjects with metabolic syndrome improves serum levels of triglyceride, high-density lipoprotein cholesterol, and fasting blood glucose.

\subsection{Banana}

Phenolic compounds are found in banana (Musa paradisiaca L.) in two forms; soluble conjugated and insoluble, covalently bound to sugars or cell wall components [168]. As the most important fraction are bound phenols rather than free ones, most of the reactions of these compounds begin when they reach the colon, where they act as chelating agents of the function of free radicals ROS and RNS, conferring the functional group in their nucleus structure [169]. Flavonoids can also inhibit enzymes, such as oxygenases (prostaglandin synthase), required in the synthesis of eicosanoids and capable of preventing the spread of bacterial and tumor metastases. Current studies have shown the ability of banana flavonoids to inhibit the main enzymes involved in cancer initiation and progression by preventing the production of nitric oxide and nuclear factor-kB [77]. It can be said that the banana, mainly the husk, is a potential source of bioactive compounds such as flavonoids and polyphenols, with a wide range of medicinal properties, in particular the high uptake of free radicals. 


\subsection{Cocoa}

Cocoa (Theobroma cacao L.), due to the high content of bioactive compounds, mainly flavonoids and phenolic acids, has demonstrated several health properties including hypolipidemic, antihyperglycemic, anticancerogenic, anti-inflammatory properties, etc. In reference to hypolipidemic properties, Sansone et al. [170] reported that daily intake of $450 \mathrm{mg}$ of cocoa flavonoids for 1 month decreases total cholesterol by $0.20 \mathrm{mmol} / \mathrm{L}$ and low-density lipoprotein cholesterol by $0.17 \mathrm{mmol} / \mathrm{L}$, whereas high-density lipoprotein cholesterol increased by $0.10 \mathrm{mmol} / \mathrm{L}$. Lin et al. [171] in a meta-analysis of 1131 participants reported that cocoa flavanol intake enhanced the biomarkers of lipid metabolism. Thus, the triglyceride levels decreased while high-density lipoprotein cholesterol increased. On the other hand, no significant changes were found for low-density lipoprotein cholesterol and total cholesterol. More recently, Davinelli et al. [172] reported that the consumption of $220 \mathrm{mg}$ of cocoa flavonoids for 4 weeks causes a reduction in total cholesterol $(-12.37 \mathrm{mg} / \mathrm{dL})$, triglycerides $(-3.81 \mathrm{mg} / \mathrm{dL})$, and plasma low-density lipoprotein cholesterol $(-14.98 \mathrm{mg} / \mathrm{dL})$, compared with baseline. Additionally, they found that plasma high-density lipoprotein increased $(+3.37 \mathrm{mg} / \mathrm{dL})$ compared with baseline.

Cocoa flavonoids have also demonstrated several anti-inflammatory properties. Thus, Álvarez-Cilleros et al. [173] reported that cocoa attenuates the levels of phospho-p65nuclear factor-kappaB and the expression of inflammatory factors including intercellular adhesion molecule-1 (ICAM-1), vascular adhesion molecule-1 (VCAM-1) and inducible nitric oxide synthase in the aortas of rats. Rossin et al. [10] reported that ethanolic extracts (rich in epicatechin and tannins) obtained from cocoa bean shell had a positive effect on the prevention of oxysterol mixture-induced InterLeukin-8 release (pro-inflammatory cytokine) on Caco-2 intestinal cell models and the prevention of exaggerated toll-like receptor 2 and 4 (TRL2 and TRL4) responses, which may contribute to oxysterol-dependent intestinal inflammation.

\subsection{Jackfruit}

The different parts of Jackfruit (Artocarpus heterophyllus L.) contain different amounts and types of phenolic compounds. Therefore, Jackfruit has proved to be a natural source of multiple flavonoids with potent biological activities, including antioxidant, anti-inflammatory, antibacterial, antineoplastic, etc., but further research is warranted to explore the health benefits and specific compounds for their better utilization.

The anti-inflammatory effect of jackfruit was analyzed by Fang et al. [79]. These authors indicated that artocarpesin (flavonoid compound) suppressed the LPS-induced production of nitric oxide (NO) and prostaglandin E2 (PGE2) through the down-regulation of inducible nitric oxide synthase (iNOS) and cyclooxygenase 2 (COX-2) protein expressions. This study was determined the inhibitory effects on the production of proinflammatory mediators in lipopolysaccharide (LPS)-activated RAW 264.7 murine macrophage cells. Jackfruit extract also had an anticancer effect. In this sense, Li et al., [77] found that the extract showed excellent antioxidant activities in HepG2 cells, liver cell models for studying diseases related to this organ.

Flavonoids have been widely associated with a wide range of biological activities, highlighting their antimicrobial activity. The possible mechanism of action of flavonoids, mainly baicalein, was demonstrated by Yang et al., [99] who reported that this occurred through the inhibition of outflow pumps which decreased their efficiency, eventually leading to cell death or apoptosis. These pumps are the major cause of resistance by microorganisms to chemical synthesis fungicides. A study characterized and analyzed the antifungal activity of jackfruit leaf extract obtained using conventional and emerging technologies and found that a concentration of $5 \mathrm{mg} / \mathrm{mL}$ showed the highest percentage of inhibition against mycelial growth of Penicillium itallicum [174]. 


\section{Conclusions}

Tropical and subtropical fruits may be considered as a very important source of nutrients and bioactive compounds, mainly flavonoids and non-flavonoid phenolics. In this way, the consumption of this type of fruit should be recommended by several health organizations around the world for its beneficial health properties. In the same way, it is important to increase awareness of the beneficial health effect of the bioactive compounds that can be obtained by tropical fruits consumption. However, apart from the indisputable benefit of consuming fruits in general and topical fruits in particular, some not so beneficial aspects have to be taken into account that are related to the sustainability of the crops, the use of pesticides for a more widespread and better production, transport costs and the environmental consequences that these entailm as well as a greater awareness in relation to fair trade.

On the other hand, several investigations around the world need to be carried out in future with the aim of focusing on the bio-accessibility and bioavailability of bioactive compounds, mainly flavonoids and non-flavonoid phenolics present in these fruits. The clarification of the several variations and alterations that tropical fruit components might suffer during the gastrointestinal digestion could provide important information which may be applied in the development of novel food, new functional food or nutraceutical products.

Author Contributions: Conceptualization, M.V.-M.; writing—original draft preparation, A.C.R.-C.; D.L.G.-M. and H.R.R.-C. writing-review and editing, S.S.-A. and M.V.-M.; supervision, S.S.-A. All authors have read and agreed to the published version of the manuscript.

Funding: This research received no external funding.

Institutional Review Board Statement: Not applicable.

Informed Consent Statement: Not applicable.

Data Availability Statement: The data presented in this study are available on request from the corresponding author.

Acknowledgments: Diana L. Garcia-Martinez grant number: 771429; Ailin C. Ramírez-Castillo grant number: 771365 and Heidi R. Ramirez-Concepcion grant number: 771579. Thanks CONACYT (National Council of Science and Technology) for the master fellowship.

Conflicts of Interest: The authors declare no conflict of interest.

\section{References}

1. Villacís-Chiriboga, J.; Elst, K.; Van Camp, J.; Vera, E.; Ruales, J. Valorization of byproducts from tropical fruits: Extraction methodologies, applications, environmental, and economic assessment: A review (Part 1: General overview of the byproducts, traditional biorefinery practices, and possible applications). Compr. Rev. Food Sci. Food Saf. 2020, 19, 405-447. [CrossRef] [PubMed]

2. Ding, P. Tropical fruits. In Encyclopedia of Applied Plant Sciences; Thomas, B., Murray, B.G., Murphy, D.J., Eds.; Academic Press: Oxford, UK, 2017; pp. 431-434.

3. Cheok, C.Y.; Mohd Adzahan, N.; Abdul Rahman, R.; Zainal Abedin, N.H.; Hussain, N.; Sulaiman, R.; Chong, G.H. Current trends of tropical fruit waste utilization. Crit. Rev. Food Sci. Nutr. 2018, 58, 335-361. [CrossRef] [PubMed]

4. Resende, L.M.; Franca, A.S. Flours based on exotic fruits and their processing residues-features and potential applications to health and disease prevention. In Flour and Breads and Their Fortification in Health and Disease Prevention; Elsevier: Amsterdam, The Netherlands, 2019; pp. 387-401, ISBN 9780128146392.

5. Altendorf, S. Major Tropical Fruits Market Review 2018; FAO: Rome, Italy, 2019; pp. 1-9.

6. De la Luz Cádiz-Gurrea, M.; del Carmen Villegas-Aguilar, M.; Leyva-Jiménez, F.J.; Pimentel-Moral, S.; Fernández-Ochoa, Á.; Alañón, M.E.; Segura-Carretero, A. Revalorization of bioactive compounds from tropical fruit by-products and industrial applications by means of sustainable approaches. Food Res. Int. 2020, 138, 109786. [CrossRef] [PubMed]

7. Arraes Maia, G.; Ribeiro da Silva, L.M.; Matias do Prado, G.; Vasconcelos Fonseca, A.V.; Machado de Sousa, P.H.; de Figueiredo, R.W. Development of Mixed Beverages Based on Tropical Fruits. In Non-Alcoholic Beverages; Grumezescu, A.M., Holban, A.M., Eds.; Woodhead Publishing: Sawston, UK, 2019; pp. 129-162. [CrossRef]

8. Alvarez-Rivera, G.; Ballesteros-Vivas, D.; Ibañez, E.; Parada-Alfonso, F.; Cifuentes, A. Foodomics of Bioactive Compounds from Tropical Fruits By-Products. In Comprehensive Foodomics; Cifuentes, A., Ed.; Elsevier: Amsterdam, The Netherlands, 2021; pp. 672-688. [CrossRef] 
9. Schulz, M.; Seraglio, S.K.T.; Brugnerotto, P.; Gonzaga, L.V.; Costa, A.C.O.; Fett, R. Composition and potential health effects of dark-colored underutilized Brazilian fruits-A review. Food Res. Int. 2020, 137, 109744. [CrossRef]

10. Can-Cauich, C.A.; Sauri-Duch, E.; Betancur-Ancona, D.; Chel-Guerrero, L.; González-Aguilar, G.A.; Cuevas-Glory, L.F.; PérezPacheco, E.; Moo-Huchin, V.M. Tropical fruit peel powders as functional ingredients: Evaluation of their bioactive compounds and antioxidant activity. J. Funct. Foods 2017, 37, 501-506. [CrossRef]

11. Pereira-Netto, A.B. Tropical fruits as natural, exceptionally rich, sources of bioactive compounds. Int. J. Fruit Sci. 2018, 18, 231-242. [CrossRef]

12. Azizan, A.; Lee, A.X.; Hamid, N.A.A.; Maulidiani, M.; Mediani, A.; Ghafar, S.Z.A.; Zolkeflee, N.K.Z.; Abas, F. Potentially bioactive metabolites from pineapple waste extracts and their antioxidant and $\alpha$-glucosidase inhibitory activities by $1 \mathrm{H}$ NMR. Foods $\mathbf{2 0 2 0}$ 9, 173. [CrossRef]

13. Pirozzi, A.V.A.; Imbimbo, P.; D’agostino, A.; Tirino, V.; Finamore, R.; Monti, D.M.; Piccoli, R.; Schiraldi, C. Antioxidant and hypolipidemic activity of açai fruit makes it a valuable functional food. Antioxidants 2021, 10, 40. [CrossRef]

14. El-Hadary, A.E.; Ramadan, M.F. Phenolic profiles, antihyperglycemic, antihyperlipidemic, and antioxidant properties of pomegranate (Punica granatum) peel extract. J. Food Biochem. 2019, 43, 1-9. [CrossRef]

15. Gómez-García, A.C.; Peñaloza, J.; Cañas, J.; Rojano, B.; Ramos, A.R.; Maldonado, M.E. Impact of Colombian yellow fruits and tropical fruits drinks consumption on the antioxidant status of healthy women. J. Med. Plant. Res. 2019, 10, 529-537. [CrossRef]

16. Arbizu-Berrocal, S.H.; Kim, H.; Fang, C.; Krenek, K.A.; Talcott, S.T.; Mertens-Talcott, S.U. Polyphenols from mango (Mangifera indica L.) modulate PI3K/AKT/mTOR-associated micro-RNAs and reduce inflammation in non-cancer and induce cell death in breast cancer cells. J. Funct. Foods 2019, 55, 9-16. [CrossRef]

17. Dabas, D.; Elias, R.J.; Ziegler, G.R.; Lambert, J.D. In vitro antioxidant and cancer inhibitory activity of a colored avocado seed extract. Int. J. Food Sci. 2019, 2019, 6509421. [CrossRef]

18. Horie, K.; Hossain, M.S.; Morita, S.; Kim, Y.; Yamatsu, A.; Watanabe, Y.; Ohgitani, E.; Mazda, O.; Kim, M. The potency of a novel fermented unripe banana powder as a functional immunostimulatory food ingredient. J. Funct. Foods 2020, 70, 103980. [CrossRef]

19. De Albuquerque, M.A.C.; Levit, R.; Beres, C.; Bedani, R.; de Moreno de LeBlanc, A.; Saad, S.M.I.; LeBlanc, J.G. Tropical fruit by-products water extracts of tropical fruit by-products as sources of soluble fibres and phenolic compounds with potential antioxidant, anti-inflammatory, and functional properties. J. Funct. Foods 2019, 52, 724-733. [CrossRef]

20. Singh, P.G.; Madhu, S.B.; Shailasree, S.; TS, G.; Basalingappa, K.M.; BV, S. In Vitro Antioxidant, Anti-Inflammatory and AntiMicrobial Activity of Carica Papaya Seeds. Glob. J. Med. Res. 2020, 20, 19-38. [CrossRef]

21. Rodríguez-González, S.; Gutiérrez-Ruíz, I.M.; Pérez-Ramírez, I.F.; Mora, O.; Ramos-Gomez, M.; Reynoso-Camacho, R. Mechanisms related to the anti-diabetic properties of mango (Mangifera indica L.) juice by-product. J. Funct. Foods 2017, 37, 190-199. [CrossRef]

22. Lasano, N.F.; Hamid, A.H.; Karim, R.; Dek, M.S.P.; Shukri, R.; Ramli, N.S. Nutritional Composition, Anti-Diabetic Properties and Identification of Active Compounds Using UHPLC-ESI-Orbitrap-MS/MS in Mangifera odorata L. Peel and seed kernel. Molecules 2019, 24, 320. [CrossRef]

23. Fidelis, M.; do Carmo, M.A.V.; da Cruz, T.M.; Azevedo, L.; Myoda, T.; Miranda Furtado, M.; Marques, M.B.; Sant'Ana, A.S.; Genovese, M.I.; Oh, W.Y.; et al. Camu-camu seed (Myrciaria dubia)—From side stream to an antioxidant, antihyperglycemic, antiproliferative, antimicrobial, antihemolytic, anti-inflammatory, and antihypertensive ingredient. Food Chem. 2020, 310, 125909. [CrossRef]

24. Tanghe, A.; Heyman, E.; Vanden Wyngaert, K.; Van Ginckel, A.; Celie, B.; Rietzschel, E.; Calders, P.; Shadid, S. Evaluation of blood pressure lowering effects of cocoa flavanols in diabetes mellitus: A systematic review and meta-analysis. J. Funct. Foods 2021, 79, 104399. [CrossRef]

25. Xiong, J.; Matta, F.V.; Grace, M.; Lila, M.A.; Ward, N.I.; Felipe-Sotelo, M.; Esposito, D. Phenolic content, anti-inflammatory properties, and dermal wound repair properties of industrially processed and non-processed acai from the Brazilian Amazon. Food Funct. 2020, 11, 4903-4914. [CrossRef]

26. Norhaslinda, R.; Noratiqah, J.M.; Amin, B.A.; Khalili, R.M.A. Quantitative and optimization of anthocyanin extracted from pomegranate (Punica granatum) extract by High-Performance Liquid Chromatography (HPLC). Pharmacogn. J. 2018, 10, 650-653. [CrossRef]

27. Viganó, J.; Brumer, I.Z.; de Campos Braga, P.A.; da Silva, J.K.; Maróstica Júnior, M.R.; Reyes Reyes, F.G.; Martínez, J. Pressurized liquids extraction as an alternative process to readily obtain bioactive compounds from passion fruit rinds. Food Bioprod. Process. 2016, 100, 382-390. [CrossRef]

28. Nunes, J.C.; Lago, M.G.; Castelo-Branco, V.N.; Oliveira, F.R.; Guedes Torres, A.; Perrone, D.; Monteiro, M. Effect of drying method on volatile compounds, phenolic profile and antioxidant capacity of guava powders. Food Chem. 2016, 197, 881-890. [CrossRef]

29. Sun, G.M.; Zhang, X.M.; Soler, A.; Marie-Alphonsine, P.A. Chapter 25-Nutritional Composition of Pineapple (Ananas comosus (L.) Merr.). In Nutritional Composition of Fruit Cultivars; Simmonds, M.S.J., Preedy, V.R., Eds.; Academic Press: Oxford, UK, 2016; pp. 609-637. [CrossRef]

30. Marcillo-Parra, V.; Anaguano, M.; Molina, M.; Tupuna-Yerovi, D.S.; Ruales, J. Characterization and quantification of bioactive compounds and antioxidant activity in three different varieties of mango (Mangifera indica L.) peel from the Ecuadorian region using HPLC-UV/VIS and UPLC-PDA. NFS J. 2021, 23, 1-7. [CrossRef] 
31. Trujillo-Mayol, I.; Badillo-Muñoz, G.; Céspedes-Acuña, C.; Alarcón-Enos, J. The relationship between fruit size and phenolic and enzymatic composition of avocado byproducts (Persea americana mill.): The importance for biorefinery applications. Horticulturae 2020, 6, 91. [CrossRef]

32. Bressiani, P.A.; De Lima, G.R.F.; Düsman, E.; Tonin, L.T.D. Cytotoxic and antioxidant activities of Tamarindus indica pulp extract from Brazil. J. Food Meas. Charact. 2021, 15, 2743-2749. [CrossRef]

33. Arivalagan, M.; Roy, T.K.; Yasmeen, A.M.; Pavithra, K.C.; Jwala, P.N.; Shivasankara, K.S.; Manikantan, M.R.; Hebbar, K.B.; Kanade, S.R. Extraction of phenolic compounds with antioxidant potential from coconut (Cocos nucifera L.) testa and identification of phenolic acids and flavonoids using UPLC coupled with TQD-MS/MS. LWT Food Sci. Technol. 2018, 92, 116-126. [CrossRef]

34. Botella-Martínez, C.; Lucas-Gonzalez, R.; Ballester-Costa, C.; Pérez-Álvarez, J.Á.; Fernández-López, J.; Delgado-Ospina, J.; Chaves-López, C.; Viuda-Martos, M. Ghanaian cocoa (Theobroma cacao L.) bean shells coproducts: Effect of particle size on chemical composition, bioactive compound content and antioxidant activity. Agronomy 2021, 11, 401. [CrossRef]

35. Anyasi, T.A.; Jideani, A.I.O.; Mchau, G.R.A. Phenolics and essential mineral profile of organic acid pretreated unripe banana flour. Food Res. Int. 2018, 104, 100-109. [CrossRef]

36. Wang, X.L.; Di, X.X.; Shen, T.; Wang, S.Q.; Wang, X.N. New phenolic compounds from the leaves of Artocarpus heterophyllus. Chin. Chem. Lett. 2016, 28, 37-40. [CrossRef]

37. Latos-Brozio, M.; Masek, A. Structure-activity relationships analysis of monomeric and polymeric polyphenols (quercetin, rutin and catechin) obtained by various polymerization methods. Chem. Biodivers. 2019, 16, e1900426. [CrossRef] [PubMed]

38. Garzón, G.A.; Narváez-Cuenca, C.E.; Vincken, J.P.; Gruppen, H. Polyphenolic composition and antioxidant activity of açai (Euterpe oleracea Mart.) from Colombia. Food Chem. 2017, 217, 364-372. [CrossRef] [PubMed]

39. Crespo-López, M.E.; Soares, E.S.; de Matos Macchi, B.; Santos-Sacramento, L.; Takeda, P.Y.; Lopes-Araújo, A.; de Oliveira Paraense, R.S.; Souza-Monteiro, J.R.; Augusto-Oliveira, M.; Luz, D.A.; et al. Towards therapeutic alternatives for mercury neurotoxicity in the amazon: Unraveling the pre-clinical effects of the superfruit açaí (Euterpe oleracea, mart.) as juice for human consumption. Nutrients 2019, 11, 2585. [CrossRef] [PubMed]

40. Melo, P.S.; Massarioli, A.P.; Lazarini, J.G.; Soares, J.C.; Franchin, M.; Rosalen, P.L.; de Alencar, S.M. Simulated gastrointestinal digestion of Brazilian açaí seeds affects the content of flavan-3-ol derivatives, and their antioxidant and anti-inflammatory activities. Heliyon 2020, 6, e05214. [CrossRef]

41. Haghighian, M.K.; Rafraf, M.; Hemmati, S.; Haghravan, S.; Asghari-Jafarabadi, M. Effects of pomegranate (Punica granatum L.) peel extract supplementation on serum lipid profile and oxidative stress in obese women with knee osteoarthritis: A double blind, randomized, placebo controlled study. Adv. Integr. Med. 2020, 8, 107-113. [CrossRef]

42. Rongai, D.; Pulcini, P.; Di Lernia, G.; Nota, P.; Preka, P.; Milano, F. Punicalagin content and antifungal activity of different pomegranate (Punica ganatum L.) genotypes. Horticulturae 2019, 5, 52. [CrossRef]

43. Kostka, T.; Ostberg-Potthoff, J.J.; Briviba, K.; Matsugo, S.; Winterhalter, P.; Esatbeyoglu, T. Pomegranate (Punica granatum L.) extract and its anthocyanin and copigment fractions-free radical scavenging activity and influence on cellular oxidative stress. Foods 2020, 9, 1617. [CrossRef]

44. Díaz-Mula, H.M.; Tomás-Barberán, F.A.; García-Villalba, R. Pomegranate fruit and juice (cv. Mollar), rich in ellagitannins and anthocyanins, also provide a significant content of a wide range of proanthocyanidins. J. Agric. Food Chem. 2019, 67, 9160-9167. [CrossRef]

45. De Souza, C.G.; Rodrigues, T.H.S.; de Silva, L.M.A.; Ribeiro, P.R.V.; de Brito, E.S. Sequential extraction of flavonoids and pectin from yellow passion fruit rind using pressurized solvent or ultrasound: Extraction of flavonoids and pectin from passion fruit. $J$. Sci. Food Agric. 2018, 98, 1362-1368. [CrossRef]

46. Carmona-Hernandez, J.C.; Taborda-Ocampo, G.; Valdez, J.C.; Bolling, B.W.; González-Correa, C.H. Polyphenol extracts from three colombian passifloras (passion fruits) prevent inflammation-induced barrier dysfunction of Caco-2 cells. Molecules 2019, 24, 4614. [CrossRef]

47. Dos Reis, L.C.R.; Facco, E.M.P.; Salvador, M.; Hickmann Flôres, S.; de Oliveira Rios, A. Antioxidant potential and physicochemical characterization of yellow, purple and orange passion fruit. J. Food Sci. Technol. 2018, 55, 2679-2691. [CrossRef]

48. Lopes dos Santos, W.N.; da Silva Sauthier, M.C.; Pinto dos Santos, A.M.; de Andrade Santana, D.; Almeida Azevedo, R.S.; da Cruz Caldas, J. Simultaneous determination of 13 phenolic bioactive compounds in guava (Psidium guajava L.) by HPLC-PAD with evaluation using PCA and Neural Network Analysis (NNA). Microchem. J. 2017, 133, 583-592. [CrossRef]

49. Da Silva Lima, R.; Salvador Ferreira, S.R.; Vitali, L.; Block, J.M. May the superfruit red guava and its processing waste be a potential ingredient in functional foods? Food Res. Int. 2019, 115, 451-459. [CrossRef]

50. Tan, S.; Wang, Z.; Xiang, Y.; Deng, T.; Zhao, X.; Shi, S.; Zheng, Q.; Gao, X.; Li, W. The effects of drying methods on chemical profiles and antioxidant activities of two cultivars of Psidium guajava fruits. LWT Food Sci. Technol. 2020, 118, 108723. [CrossRef]

51. Rosas Dominguez, C.; Domínguez Avila, J.A.; Pareek, S.; Villegas Ochoa, M.A.; Ayala Zavala, J.F.; Yahia, E.; González-Aguilar, G.A. Content of bioactive compounds and their contribution to antioxidant capacity during ripening of pineapple (Ananas comosus L.) cv Esmeralda. J. Appl. Bot. Food Qual. 2018, 91, 61-68. [CrossRef]

52. Arampath, P.C.; Dekker, M. Bulk storage of mango (Mangifera indica L.) and pineapple (Ananas comosus L.) pulp: Effect of pulping and storage temperature on phytochemicals and antioxidant activity. J. Sci. Food Agric. 2019, 99, 5157-5167. [CrossRef] 
53. Morales, M.; Zapata, S.; Jaimes, T.R.; Rosales, S.; Alzate, A.F.; Maldonado, M.E.; Zamorano, P.; Rojano, B.A. Mangiferin content, carotenoids, tannins and oxygen radical absorbance capacity (ORAC) values of six mango (Mangifera indica) cultivars from the Colombian Caribbean. J. Med. Plants Res. 2017, 11, 144-152. [CrossRef]

54. Liu, F.C.X.; Fu, S.F.; Bi, X.F.; Chen, F.; Liao, X.J.; Hu, X.S.; Wu, H.J. Physico-chemical and antioxidant properties of four mango (Mangifera indica L.) cultivars in China. Food Chem. 2013, 138, 396-405. [CrossRef]

55. Ediriweera, M.K.; Tennekoon, K.H.; Samarakoon, S.R. A Review on Ethnopharmacological Applications, pharmacological activities, and bioactive compounds of Mangifera indica (Mango). Evid. Based Complement. Altern. Med. 2017, 2017, 6949835. [CrossRef]

56. Nguyen, N.M.P.; Le, T.T.; Vissenaekens, H.; Gonzales, G.B.; Van Camp, J.; Smagghe, G.; Raes, K. In vitro antioxidant activity and phenolic profiles of tropical fruit by-products. Int. J. Food Sci. Technol. 2019, 54, 1169-1178. [CrossRef]

57. Sáyago-Ayerdi, S.G.; Moreno-Hernández, C.L.; Montalvo-González, E.; García-Magaña, M.L.; Mata-Montes de Oca, M.; Torres, J.L.; Pérez-Jiménez, J. Mexican “Ataulfo" mango (Mangifera indica L) as a source of hydrolyzable tannins. Analysis by MALDITOF/TOF MS. Food Res. Int. 2013, 51, 188-194. [CrossRef]

58. Castro-Vargas, H.I.; Vivas, D.B.; Barbosa, J.O.; Medina, S.J.M.; Gutiérrez, F.A.; Parada-Alfonso, F. Bioactive phenolic compounds from the agroindustrial waste of Colombian mango cultivars 'sugar mango' and 'tommy atkins'—An alternative for their use and valorization. Antioxidants 2019, 8, 41. [CrossRef]

59. Mwaurah, P.W.; Kumar, S.; Kumar, N.; Panghal, A.; Attkan, A.K.; Singh, V.K.; Garg, M.K. Physicochemical characteristics, bioactive compounds and industrial applications of mango kernel and its products: A review. Compr. Rev. Food Sci. Food Saf. 2020, 19, 2421-2446. [CrossRef]

60. Salazar-López, N.J.; Domínguez-Avila, J.A.; Yahia, E.M.; Belmonte-Herrera, B.H.; Wall-Medrano, A.; Montalvo-González, E.; González-Aguilar, G.A. Avocado fruit and by-products as potential sources of bioactive compounds. Food Res. Int. 2020, 138, 109774. [CrossRef]

61. Araujo, R.G.; Rodríguez-Jasso, R.M.; Ruíz, H.A.; Govea-Salas, M.; Pintado, M.; Aguilar, C.N. Recovery of bioactive components from avocado peels using microwave-assisted extraction. Food Bioprod. Process. 2021, 127, 152-161. [CrossRef]

62. Ramos-Aguilar, A.L.; Ornelas-Paz, J.; Tapia-Vargas, L.M.; Gardea-Béjar, A.A.; Yahia, E.M.; de Jesus Ornelas-Paz, J.; Ruiz-Cruz, S.; Rios-Velasco, C.; Escalante-Minakata, P. Effect of cultivar on the content of selected phytochemicals in avocado peels. Food Res. Int. 2021, 140, 110024. [CrossRef]

63. Saavedra, J.; Córdova, A.; Navarro, R.; Díaz-Calderón, P.; Fuentealba, C.; Astudillo-Castro, C.; Toledo, L.; Enrione, J.; Galvez, L. Industrial avocado waste: Functional compounds preservation by convective drying process. J. Food Eng. 2017, 198, 81-90. [CrossRef]

64. López-Cobo, A.; Gómez-Caravaca, A.M.; Pasini, F.; Caboni, M.F.; Segura-Carretero, A.; Fernández-Gutiérrez, A. HPLC-DAD-ESIQTOF-MS and HPLC-FLD-MS as valuable tools for the determination of phenolic and other polar compounds in the edible part and by-products of avocado. LWT Food Sci. Technol. 2016, 73, 505-513. [CrossRef]

65. Tril, U.; Fernández-López, J.; Pérez Álvarez, J.A.; Viuda-Martos, M. Chemical, physicochemical, technological, antibacterial and antioxidant properties of rich-fibre powder extract obtained from tamarind (Tamarindus indica L.). Ind. Crop. Prod. 2014, 55, 155-162. [CrossRef]

66. Nabeel, K.; Fathima, A.; Khanum, F.; Manjula, S.N.; Mruthunjaya, K.; Vengal Rao, P.; Mehdi, S. Anti-obesity effect of tamarindus indicus seed extract against a high-fat diet-induced obese model in rats. Int. J. Res. Pharm. Sci. 2020, 11, 2083-2089. [CrossRef]

67. Cvetanović, A.; Uysal, S.; Pavlić, B.; Sinan, K.I.; Llorent-Martínez, E.J.; Zengin, G. Tamarindus indica L. Seed: Optimization of Maceration Extraction Recovery of Tannins. Food Anal. Methods 2020, 13, 579-590. [CrossRef]

68. Govindappa, M.; Birawat, R.K.A.; Raghavendra, V.B.; Munawer, U.; Ningaraju, S.; Al-Rashed, S.; Chowdappa, S.; Pugazhendhi, A. In vitro therapeutic evaluation of nanoliposome loaded with Xyloglucans polysaccharides from Tamarindus flower extract. Int. J. Biol. Macromol. 2021, 178, 283-295. [CrossRef] [PubMed]

69. Jericó Santos, T.R.; Santos Vasconcelos, A.G.; Lins de Aquino Santana, L.C.; Gualberto, N.C.; Buarque Feitosa, P.R.; Pires de Siqueira, A.C. Solid-state fermentation as a tool to enhance the polyphenolic compound contents of acidic Tamarindus indica by-products. Biocatal. Agric. Biotechnol. 2020, 30, 101851. [CrossRef]

70. El-Haddad, A.E.S.; Saadeldeen, A.M.; El-Emam, S.Z. Anti-angiogenic activity of major phenolics in tamarind assessed with molecular docking study on vegf kinase proteins. Pakistan J. Biol. Sci. 2019, 22, 502-509. [CrossRef] [PubMed]

71. Mahayothee, B.; Koomyart, I.; Khuwijitjaru, P.; Siriwongwilaichat, P.; Nagle, M.; Müller, J. Phenolic compounds, antioxidant activity, and medium chain fatty acids profiles of coconut water and meat at different maturity stages. Int. J. Food Prop. 2016, 19, 2041-2051. [CrossRef]

72. Li, N.; Jiang, H.; Yang, J.; Wang, C.; Wu, L.; Hao, Y.; Liu, Y. Characterization of phenolic compounds and anti-acetylcholinase activity of coconut shells. Food Biosci. 2021, 42, 101204. [CrossRef]

73. Mulyadi, A.F.; Schreiner, M.; Dewi, I.A. Phenolic and volatile compounds, antioxidant activity, and sensory properties of virgin coconut oil: Occurrence and their relationship with quality. AIP Conf. Proc. 2018, 2021, 070020. [CrossRef]

74. Peláez, P.; Bardón, I.; Camasca, P. Methylxanthine and catechin content of fresh and fermented cocoa beans, dried cocoa beans, and cocoa liquor. Sci. Agropecu. 2016, 7, 355-365. [CrossRef] 
75. Urbańska, B.; Kowalska, H.; Szulc, K.; Ziarno, M.; Pochitskaya, I.; Kowalska, J. Comparison of the effects of douching parameters on the contents of three dominant flavan3-ols, rheological properties and sensory quality in chocolate milk mass based on liquor from unroasted cocoa beans. Molecules 2021, 26, 2502. [CrossRef]

76. Hernández-Hernández, C.; Morales-Sillero, A.; Fernández-Bolaños, J.; Bermúdez-Oria, A.; Morales, A.A.; Rodríguez-Gutiérrez, G. Cocoa bean husk: Industrial source of antioxidant phenolic extract. J. Sci. Food Agric. 2019, 99, 325-333. [CrossRef]

77. Oliveira, B.G.; Pimentel, E.F.; Pereira, A.C.H.; Tosato, F.; Pinto, F.E.; Ventura, J.A.; Endringer, D.C.; Romão, W. Phenolic and glycidic profiling of bananas Musa spp. associated with maturation stage and cancer chemoprevention activities. Microchem. J. 2020, 153, 104391. [CrossRef]

78. Lopes, S.; Borges, C.V.; Sousa Cardoso, S.M.; Almeida Pereira da Rocha, M.F.; Maraschin, M. Banana (Musa spp.) as a source of bioactive compounds for health promotion. Handb. Banan. Prod. Postharvest Sci. Process. Technol. Nutr. 2020, 227-244. [CrossRef]

79. Li, Z.; Lan, Y.; Miao, J.; Chen, X.; Chen, B.; Liu, G.; Wu, X.; Zhu, X.; Cao, Y. Phytochemicals, antioxidant capacity and cytoprotective effects of jackfruit (Artocarpus heterophyllus Lam.) axis extracts on HepG2 cells. Food Biosci. 2021, 41, 100933. [CrossRef]

80. Fang, S.C.; Hsu, C.L.; Yen, G.C. Anti-inflammatory effects of phenolic compounds isolated from the fruits of Artocarpus heterophyllus. J. Agric. Food Chem. 2008, 56, 4463-4468. [CrossRef]

81. Wojdyło, A.; Nowicka, P.; Oszmiański, J.; Golis, T. Phytochemical compounds and biological effects of Actinidia fruits. J. Funct. Foods 2017, 30, 194-202. [CrossRef]

82. Guedes, T.J.F.L.; Rajan, M.; Barbosa, P.F.; Silva, E.S.; Machado, T.O.X.; Narain, N. Phytochemical composition and antioxidant potential of different varieties viz. Flor Branca, Costa Rica and Junco of green unripe acerola (Malphigia emarginata D.C.) fruits. Food Sci. Technol. 2020, 12, 1-9. [CrossRef]

83. Batista, A.C.V.; de Alencar Ribeiro, M.; Alves de Oliveira, K.; de Freitas, P.A.; dos Santos, N.S.; Magalhães, L.A.; Magalhães, S.C.; da Cruz Fonseca, S.G.; de Souza Aquino, J.; de Souza, E.L.; et al. Effects of consumption of acerola, cashew and guava by-products on adiposity and redox homeostasis of adipose tissue in obese rats. Clin. Nutr. ESPEN 2021, 43, 283-289. [CrossRef]

84. Pimenta Inada, K.O.; Nunes, S.; Martínez-Blázquez, J.A.; Tomás-Barberán, F.A.; Perrone, D.; Monteiro, M. Effect of high hydrostatic pressure and drying methods on phenolic compounds profile of jabuticaba (Myrciaria jaboticaba) peel and seed. Food Chem. 2020, 309, 125794. [CrossRef]

85. Fidelis, M.; Santos, J.S.; Escher, G.B.; Rocha, R.S.; Cruz, A.G.; Cruz, T.M.; Marques, M.B.; Nunes, J.B.; do Carmo, M.A.V.; de Almeida, L.A.; et al. Polyphenols of jabuticaba [Myrciaria jaboticaba (Vell.) O.Berg] seeds incorporated in a yogurt model exert antioxidant activity and modulate gut microbiota of 1,2-dimethylhydrazine-induced colon cancer in rats. Food Chem. 2021, 334, 127565. [CrossRef]

86. Mehdizadeh, S.; Lasekan, O.; Muhammad, K.; Baharin, B. Variability in the fermentation index, polyphenols and amino acids of seeds of rambutan (Nephelium lappaceum L.) during fermentation. J. Food Compos. Anal. 2015, 37, 128-135. [CrossRef]

87. Man, S.; Ma, J.; Wang, C.; Li, Y.; Gao, W.; Lu, F. Chemical composition and hypoglycaemic effect of polyphenol extracts from Litchi chinensis seeds. J. Funct. Foods 2016, 22, 313-324. [CrossRef]

88. Paśko, P.; Galanty, A.; Zagrodzki, P.; Luksirikul, P.; Barasch, D.; Nemirovski, A.; Gorinstein, S. Dragon fruits as a reservoir of natural polyphenolics with chemopreventive properties. Molecules 2021, 26, 2158. [CrossRef] [PubMed]

89. Lucas-González, R.; Fernández-López, J.; Pérez-Álvarez, J.Á.; Viuda-Martos, M. Effect of particle size on phytochemical composition and antioxidant properties of two persimmon flours from Diospyros kaki Thunb. vars. 'Rojo Brillante' and 'Triumph' co-products. J. Sci. Food Agric. 2018, 98, 504-510. [CrossRef] [PubMed]

90. Tang, Y.Y.; He, X.M.; Sun, J.; Li, C.B.; Li, L.; Sheng, J.F.; Xin, M.; Li, Z.C.; Zheng, F.J.; Liu, G.M.; et al. Polyphenols and alkaloids in byproducts of longan fruits (Dimocarpus longan Lour.) and their bioactivities. Molecules 2019, 24, 1186. [CrossRef]

91. Fidelis, M.; Santos, J.S.; Escher, G.B.; Vieira do Carmo, M.; Azevedo, L.; Cristina da Silva, M.; Putnik, P.; Granato, D. In vitro antioxidant and antihypertensive compounds from camu-camu (Myrciaria dubia McVaugh, Myrtaceae) seed coat: A multivariate structure-activity study. Food Chem. Toxicol. 2018, 120, 479-490. [CrossRef]

92. De Azevêdo, J.C.S.; Fujita, A.; de Oliveira, E.L.; Genovese, M.I.; Correia, R.T.P. Dried camu-camu (Myrciaria dubia H.B.K. McVaugh) industrial residue: A bioactive-rich Amazonian powder with functional attributes. Food Res. Int. 2014, 62, 934-940. [CrossRef]

93. Bittová, M.; Hladůvková, D.; Roblová, V.; Kráčmar, S.; Kubáň, P.; Kubáň, V. Analysis of organic acids, deacetyl asperulosidic acid and polyphenolic compounds as a potential tool for characterization of noni (Morinda citrifolia) products. Nat. Prod. Commun. 2015, 10, 1817-1820. [CrossRef]

94. Jamaludin, R.; Kim, D.S.; Md Salleh, L.; Lim, S. Bin Optimization of high hydrostatic pressure extraction of bioactive compounds from noni fruits. J. Food Meas. Charact. 2020, 14, 2810-2818. [CrossRef]

95. Martín Ortega, A.M.; Segura Campos, M.R. Bioactive compounds as Therapeutic alternatives. In Bioactive Compounds; Campos, M.R.S., Ed.; Woodhead Publishing: Duxford, UK, 2019; pp. 247-264.

96. Pan, L.; Duan, Y.; Ma, F.; Lou, L. Punicalagin inhibits the viability, migration, invasion, and EMT by regulating GOLPH3 in breast cancer cells. J. Recept. Signal. Transduct. 2020, 40, 173-180. [CrossRef]

97. Guo, X.D.; Zhang, D.Y.; Gao, X.J.; Parry, J.; Liu, K.; Liu, B.L.; Wang, M. Quercetin and quercetin-3-O-glucuronide are equally effective in ameliorating endothelial insulin resistance through inhibition of reactive oxygen species-associated inflammation. Mol. Nutr. Food Res. 2013, 57, 1037-1045. [CrossRef]

98. Boo, Y.C. Emerging Strategies to Protect the Skin from Ultraviolet Rays Using Plant-Derived Materials. Antioxidants 2020, 9, 637. [CrossRef] 
99. Wojnar, W.; Zych, M.; Kaczmarczyk-Sedlak, I. Antioxidative effect of flavonoid naringenin in the lenses of type 1 diabetic rats. Biomed. Pharmacother. 2018, 108, 974-984. [CrossRef]

100. Yang, S.; Zhou, J.; Li, D.; Shang, C.; Peng, L.; Pan, S. The structure-antifungal activity relationship of 5,7-dihydroxyflavonoids against Penicillium itallicum. Food Chem. 2017, 224, 26-31. [CrossRef]

101. Bhadoriya, S.S.; Ganeshpurkar, A.; Bhadoriya, R.P.S.; Sahu, S.K.; Patel, J.R. Antidiabetic potential of polyphenolic-rich fraction of Tamarindus indica seed coat in alloxan-induced diabetic rats. J. Basic Clin. Physiol. Pharmacol. 2018, 29, 37-45. [CrossRef]

102. Barros, L.; Calhelha, R.C.; Queiroz, M.J.R.P.; Santos-Buelga, C.; Santos, E.A.; Regis, W.C.B.; Ferreira, I.C.F.R. The powerful in vitro bioactivity of Euterpe oleracea Mart. seeds and related phenolic compounds. Ind. Crops Prod. 2015, 76, 318-322. [CrossRef]

103. Tremocoldi, M.A.; Rosalen, P.L.; Franchin, M.; Massarioli, A.P.; Denny, C.; Daiuto, É.R.; Paschoal, J.A.R.; Melo, P.S.; De Alencar, S.M. Exploration of avocado by-products as natural sources of bioactive compounds. PLoS ONE 2018, 13, e0192577. [CrossRef]

104. Powar, A.; Gupta, A.; Kamble, S.; Shinde, B. Immunosuppressive and antidiabetic activity of polyphenols from Musa paradisiaca. Eur. J. Biotech. Biosci. 2017, 5, 62-65.

105. Rossin, D.; Barbosa-Pereira, L.; Iaia, N.; Testa, G.; Sottero, B.; Poli, G.; Zeppa, G.; Biasi, F. A dietary mixture of oxysterols induces in vitro intestinal inflammation through TLR2/4 activation: The protective effect of cocoa bean shells. Antioxidants $2019,8,151$. [CrossRef]

106. Youryon, P.; Supapvanich, S. Physicochemical quality and antioxidant changes in 'Leb Mue Nang' banana fruit during ripening. Agric. Nat. Resour. 2017, 51, 47-52. [CrossRef]

107. Fragoso, M.F.; Romualdo, G.R.; Vanderveer, L.A.; Franco-Barraza, J.; Cukierman, E.; Clapper, M.L.; Carvalho, R.F.; Barbisan, L.F. Lyophilized açaí pulp (Euterpe oleracea Mart) attenuates colitis-associated colon carcinogenesis while its main anthocyanin has the potential to affect the motility of colon cancer cells. Food Chem. Toxicol. 2018, 121, 237-245. [CrossRef]

108. Enayati, A.; Yassa, N.; Mazaheri, Z.; Rajaei, M.; Pourabouk, M.; Ghorghanlu, S.; Basiri, S.; Khori, V. Cardioprotective and anti-apoptotic effects of Potentilla reptans L. root via Nrf2 pathway in an isolated rat heart ischemia/reperfusion model. Life Sci. 2018, 215, 216-226. [CrossRef]

109. Sheela, D.L.; Nazeem, P.A.; Narayanankutty, A.; Shylaja, R.M.; Davis, S.P.; James, P.; Valsalan, R.; Devassy Babu, T.; Raghavamenon, A.C. Coconut phytocompounds inhibits polyol pathway enzymes: Implication in prevention of microvascular diabetic complications. Prostaglandins Leukot. Essent. Fat. Acids 2017, 127, 20-24. [CrossRef]

110. Sgarbossa, A.; Giacomazza, D.; di Carlo, M. Ferulic acid: A hope for alzheimer's disease therapy from plants. Nutrients 2015, 7, 5764-5782. [CrossRef]

111. Verma, S.; Singh, A.; Mishra, A. Gallic acid: Molecular rival of cancer. Environ. Toxicol. Pharmacol. 2013, 35, 473-485. [CrossRef]

112. Dludla, P.V.; Nkambule, B.B.; Jack, B.; Mkandla, Z.; Mutize, T.; Silvestri, S.; Orlando, P.; Tiano, L.; Louw, J.; Mazibuko-Mbeje, S.E. Inflammation and oxidative stress in an obese state and the protective effects of gallic acid. Nutrients 2019, 11, 23. [CrossRef]

113. Badhani, B.; Sharma, N.; Kakkar, R. Gallic acid: A versatile antioxidant with promising therapeutic and industrial applications. RSC Adv. 2015, 5, 27540-27557. [CrossRef]

114. BenSaad, L.A.; Kim, K.H.; Quah, C.C.; Kim, W.R.; Shahimi, M. Anti-inflammatory potential of ellagic acid, gallic acid and punicalagin A\&B isolated from Punica granatum. BMC Complement. Altern. Med. 2017, 17, 47. [CrossRef]

115. Gold-Smith, F.; Fernandez, A.; Bishop, K. Mangiferin and cancer: Mechanisms of action. Nutrients 2016, 8, 396. [CrossRef]

116. Feng, S.T.; Wang, Z.Z.; Yuan, Y.H.; Sun, H.M.; Chen, N.H.; Zhang, Y. Mangiferin: A multipotent natural product preventing neurodegeneration in Alzheimer's and Parkinson's disease models. Pharmacol. Res. 2019, 146, 104336. [CrossRef]

117. Maurmann, N.; De Farias, C.B.; Schwartsmann, G.; Roesler, R.; Delgado-Hernández, R.; Pardo-Andreu, G.L. Mangifera indica L. extract (vimang) improves the aversive memory in spinocerebellar ataxia type 2 transgenic mice. J. Pharm. Pharmacogn. Res. 2014, 2, 63-72.

118. Canuto, K.M. Propriedades Químicas e Farmacológicas de Mangiferina: Um Composto Bioativo de Manga (Mangifera indica L.); Embrapa: Brasilia, Brasil, 2009; pp. 10-11.

119. Garrido, G.; González, D.; Lemus, Y.; García, D.; Lodeiro, L.; Quintero, G.; Delporte, C.; Núñez-Sellés, A.J.; Delgado, R. In vivo and in vitro anti-inflammatory activity of Mangifera indica L. extract (VIMANG®). Pharmacol. Res. 2004, 50, 143-149. [CrossRef] [PubMed]

120. Hsun-Wei Huang, T.; Peng, G.; Qian Li, G.; Yamahara, J.; Roufogalis, B.D.; Li, Y. Salacia oblonga root improves postprandial hyperlipidemia and hepatic steatosis in Zucker diabetic fatty rats: Activation of PPAR- $\alpha$. Toxicol. Appl. Pharmacol. 2006, 210, 225-235. [CrossRef] [PubMed]

121. De Almeida Magalhães, T.S.S.; de Oliveira Macedo, P.C.; Converti, A.; Neves de Lima, Á.A. The use of Euterpe oleracea Mart. as a new perspective for disease treatment and prevention. Biomolecules 2020, 10, 813. [CrossRef] [PubMed]

122. Da Silveira Vasconcelos, M.; Freitas Mota, E.; Gomes-Rochette, N.F.; Sousa Nunes-Pinheiro, D.C.; Nabavi, S.M.; Fernandes de Melo, D. Açai or Brazilian Berry (Euterpe oleracea). In Nonvitamin and Nonmineral Nutritional Supplements; Nabavi, S.M., Sanches Silva, A., Eds.; Academic Press: Oxford, UK, 2019; pp. 131-133. [CrossRef]

123. Martinez, R.M.; De Almeida Bauer Guimarães, D.; Berniz, C.R.; De Abreu, J.P.; Da Rocha, A.P.M.; De Moura, R.S.; Resende, A.C.; Teodoro, A.J. Açai (Euterpe oleracea Mart.) seed extract induces cell cycle arrest and apoptosis in human lung carcinoma cells. Foods 2018, 7, 178. [CrossRef] 
124. De Liz, S.; Cardoso, A.L.; Copetti, C.L.K.; de Fragas Hinnig, P.; Vieira, F.G.K.; da Silva, E.L.; Schulz, M.; Fett, R.; Micke, G.A.; Di Pietro, P.F. Açaí (Euterpe oleracea Mart.) and juçara (Euterpe edulis Mart.) juices improved HDL-c levels and antioxidant defense of healthy adults in a 4-week randomized cross-over study. Clin. Nutr. 2020, 39, 3629-3636. [CrossRef]

125. Aranha, L.N.; Silva, M.G.; Uehara, S.K.; Luiz, R.R.; Nogueira Neto, J.F.; Rosa, G.; Moraes de Oliveira, G.M. Effects of a hypoenergetic diet associated with açaí (Euterpe oleracea Mart.) pulp consumption on antioxidant status, oxidative stress and inflammatory biomarkers in overweight, dyslipidemic individuals. Clin. Nutr. 2020, 39, 1464-1469. [CrossRef]

126. Pala, D.; Barbosa, P.O.; Silva, C.T.; de Souza, M.O.; Freitas, F.R.; Volp, A.C.P.; Maranhão, R.C.; de Freitas, R.N. Açai (Euterpe oleracea Mart.) dietary intake affects plasma lipids, apolipoproteins, cholesteryl ester transfer to high-density lipoprotein and redox metabolism: A prospective study in women. Clin. Nutr. 2018, 37, 618-623. [CrossRef]

127. Choi, Y.J.; Choi, Y.J.; Kim, N.; Nam, R.H.; Lee, S.; Lee, H.S.; Lee, H.N.; Surh, Y.J.; Lee, D.H. Açaí berries inhibit colon tumorigenesis in azoxymethane/dextran sulfate sodium-treated mice. Gut Liver 2017, 11, 243-252. [CrossRef]

128. Martins, G.R.; do Amaral, F.R.L.; Brum, F.L.; Mohana-Borges, R.; de Moura, S.S.T.; Ferreira, F.A.; Sangenito, L.S.; Santos, A.L.S.; Figueiredo, N.G.; da Silva, A.S.A. Chemical characterization, antioxidant and antimicrobial activities of açaí seed (Euterpe oleracea Mart.) extracts containing A- and B-type procyanidins. LWT Food Sci. Tecnol. 2020, 132, 109830. [CrossRef]

129. Topalović, A.; Knežević, M.; Gačnik, S.; Mikulic-Petkovsek, M. Detailed chemical composition of juice from autochthonous pomegranate genotypes (Punica granatum L.) grown in different locations in Montenegro. Food Chem. 2020, 330, 127261. [CrossRef]

130. Grabež, M.; Škrbić, R.; Stojiljković, M.P.; Rudić-Grujić, V.; Paunović, M.; Arsić, A.; Petrović, S.; Vučić, V.; Mirjanić-Azarić, B.; Šavikin, K.; et al. Beneficial effects of pomegranate peel extract on plasma lipid profile, fatty acids levels and blood pressure in patients with diabetes mellitus type-2: A randomized, double-blind, placebo-controlled study. J. Funct. Foods 2020, 64, 103692. [CrossRef]

131. Farooqi, A.A. Regulation of deregulated cell signaling pathways by pomegranate in different cancers: Re-interpretation of knowledge gaps. Semin. Cancer Biol. 2021, 73, 294-301. [CrossRef]

132. Sohrab, G.; Roshan, H.; Ebrahimof, S.; Nikpayam, O.; Sotoudeh, G.; Siasi, F. Effects of pomegranate juice consumption on blood pressure and lipid profile in patients with type 2 diabetes: A single-blind randomized clinical trial. Clin. Nutr. ESPEN 2019, 29, 30-35. [CrossRef]

133. Nasser, M.; Damaj, Z.; Hijazi, A.; Merah, O.; Al-Khatib, B.; Hijazi, N.; Trabolsi, C.; Damaj, R.; Nasser, M. Pomegranate juice extract decreases cisplatin toxicity on peripheral blood mononuclear cells. Medicines 2020, 7, 66. [CrossRef]

134. Karwasra, R.; Singh, S.; Sharma, D.; Sharma, S.; Sharma, N.; Khanna, K. Pomegranate supplementation attenuates inflammation, joint dysfunction via inhibition of NF-kB signaling pathway in experimental models of rheumatoid arthritis. J. Food Biochem. 2019, 43, e12959. [CrossRef]

135. Stojanović, I.; Šavikin, K.; Đedović, N.; Živković, J.; Saksida, T.; Momčilović, M.; Koprivica, I.; Vujičić, M.; Stanisavljević, S.; Miljković, D.; et al. Pomegranate peel extract ameliorates autoimmunity in animal models of multiple sclerosis and type 1 diabetes. J. Funct. Foods. 2017, 35, 522-530. [CrossRef]

136. Barbalho, S.M.; Damasceno, D.C.; Machado Spada, A.P.; Lima, I.E.R.N.; Cressoni Araújo, A.; Guiguer, E.L.; Martuchi, K.A.; Oshiiwa, M.; Mendes, C.G. Effects of Passiflora edulis on the Metabolic Profile of Diabetic Wistar Rat Offspring. J. Med. Food 2011, 14, 1490-1495. [CrossRef]

137. Ballesteros-Vivas, D.; Alvarez-Rivera, G.; León, C.; Morantes, S.J.; Ibánez, E.; Parada-Alfonso, F.; Cifuentes, A.; Valdés, A. Foodomics evaluation of the anti-proliferative potential of Passiflora mollissima seeds. Food Res. Int. 2020, 130, 108938. [CrossRef]

138. Fernandes Marques, S.S.; Feio Libonati, R.M.; Sabaa-Srur, A.U.O.; Luo, R.; Shejwalkar, P.; Hara, K.; Dobbs, T.; Smith, R.E. Evaluation of the effects of passion fruit peel flour (Passiflora edulis fo. flavicarpa) on metabolic changes in HIV patients with lipodystrophy syndrome secondary to antiretroviral therapy. Rev. Bras. Farmacogn. 2016, 26, 420-426. [CrossRef]

139. Kasala, E.R.; Bodduluru, L.N.; Barua, C.C.; Madhana, R.M.; Dahiya, V.; Budhani, M.K.; Mallugari, R.R.; Maramreddy, S.R.; Gogoi, R. Chemopreventive effect of chrysin, a dietary flavone against benzo(a)pyrene induced lung carcinogenesis in Swiss albino mice. Pharmacol. Rep. 2016, 68, 310-318. [CrossRef]

140. Maryanto, S.; Marsono, Y. The effect of guava on the improvement of lipid profile in hypercholesterolemic rats. IOP Conf. Ser. Earth Environ. Sci. 2019, 276, 012054. [CrossRef]

141. Shabbir, H.; Kausar, T.; Noreen, S.; ur Rehman, H.; Hussain, A.; Huang, Q.; Gani, A.; Su, S.; Nawaz, A. In vivo screening and antidiabetic potential of polyphenol extracts from guava pulp, seeds and leaves. Animals 2020, 10, 1714. [CrossRef]

142. Feng, X.; Wang, Z.; Meng, D.; Li, X. Cytotoxic and antioxidant constituents from the leaves of Psidium guajava. Bioorg. Med. Chem. Lett. 2015, 25, 2193-2198. [CrossRef]

143. Correa, M.G.; Couto, J.S.; Trindade, B.B.; Abreu, J.P.; Nakajima, V.M.; Oliveira, F.L.; Farah, A.; Teodoro, A.J. Antiproliferative effect of guava fruit extracts in MDA-MB-435 and MCF-7 human breast cancer cell lines. An. Acad. Bras. Cienc. 2020, 92, e20191500. [CrossRef]

144. Li, P.-Y.; Hsu, C.-C.; Yin, M.-C.; Kuo, Y.-H.; Tang, F.-Y.; Chao, C.-Y. Protective Effects of Red Guava on Inflammation and Oxidative Stress in Streptozotocin-Induced Diabetic Mice. Molecules 2015, 20, 22341-22350. [CrossRef]

145. Saxena, P.; Panjwani, D. Cardioprotective potential of hydro-alcoholic fruit extract of Ananas comosus against isoproterenol induced myocardial infraction in Wistar Albino rats. J. Acute. Dis. 2014, 3, 228-234. [CrossRef]

146. Seenak, P.; Kumphune, S.; Malakul, W.; Chotima, R.; Nernpermpisooth, N. Pineapple consumption reduced cardiac oxidative stress and inflammation in high cholesterol diet-fed rats. Nutr. Metab. 2021, 18, 36. [CrossRef] 
147. Kumar, M.; Saurabh, V.; Tomar, M.; Hasan, M.; Changan, S.; Sasi, M.; Maheshwari, C.; Prajapati, U.; Singh, S.; Prajapat, R.K.; et al. Mango (Mangifera indica L.) leaves: Nutritional composition, phytochemical profile, and health-promoting bioactivities. Antioxidants 2021, 10, 299. [CrossRef]

148. Alañón, M.E.; Pimentel-Moral, S.; Arráez-Román, D.; Segura-Carretero, A. HPLC-DAD-Q-ToF-MS profiling of phenolic compounds from mango (Mangifera indica L.) seed kernel of different cultivars and maturation stages as a preliminary approach to determine functional and nutraceutical value. Food Chem. 2021, 337, 127764. [CrossRef]

149. Imran, M.; Arshad, M.S.; Butt, M.S.; Kwon, J.H.; Arshad, M.U.; Sultan, M.T. Mangiferin: A natural miracle bioactive compound against lifestyle related disorders. Lipids Health Dis. 2017, 16, 84. [CrossRef]

150. Morozkina, S.N.; Vu, T.H.N.; Generalova, Y.E.; Snetkov, P.P.; Uspenskaya, M.V. Mangiferin as new potential anti-cancer agent and mangiferin-integrated polymer systems: A novel research direction. Biomolecules 2021, 11, 79. [CrossRef] [PubMed]

151. Wall-Medrano, A.; Olivas-Aguirre, F.J.; Ayala-Zavala, J.F.; Domínguez-Avila, J.A.; Gonzalez-Aguilar, G.A.; Herrera-Cazares, L.A.; Gaytan-Martinez, M. Health benefits of mango by-products. Food Wastes By-Prod. 2020, 159-191. [CrossRef]

152. Figueroa, J.G.; Borrás-Linares, I.; Lozano-Sánchez, J.; Segura-Carretero, A. Comprehensive characterization of phenolic and other polar compounds in the seed and seed coat of avocado by HPLC-DAD-ESI-QTOF-MS. Food Res. Int. 2018, 105, 752-763. [CrossRef] [PubMed]

153. Bowen, J.; Billing, D.; Connolly, P.; Smith, W.; Cooney, J.; Burdon, J. Maturity, storage and ripening effects on anti-fungal compounds in the skin of 'Hass' avocado fruit. Postharvest Biol. Technol. 2018, 146, 43-50. [CrossRef]

154. Gómez-Maqueo, A.; Escobedo-Avellaneda, Z.; Welti-Chanes, J. Phenolic compounds in mesoamerican fruits-Characterization, health potential and processing with innovative technologies. Int. J. Mol. Sci. 2020, 21, 8357. [CrossRef]

155. Ervianingsih; Hurria; Astari, C.; Mursyid, M.; Kadir, A.R. Avocado seed waste utilization into biscuits as diabetes mellitus patients' alternative foods. IOP Conf. Ser. Earth Environ. Sci. 2020, 575, 3-8. [CrossRef]

156. Alam, M.A.; Subhan, N.; Hossain, H.; Hossain, M.; Reza, H.M.; Rahman, M.M.; Ullah, M.O. Hydroxycinnamic acid derivatives: A potential class of natural compounds for the management of lipid metabolism and obesity. Nutr. Metab. 2016, 13, 1-13. [CrossRef]

157. Eldaim, M.A.; Tousson, E.; El Sayed, I.E.T.; Abd El-Aleim, A.E.A.H.; Elsharkawy, H.N. Grape seeds proanthocyanidin extract ameliorates Ehrlich solid tumor induced renal tissue and DNA damage in mice. Biomed. Pharmacother. 2019, 115, 108908. [CrossRef]

158. Maisuria, V.B.; Okshevsky, M.; Déziel, E.; Tufenkji, N. Proanthocyanidin Interferes with Intrinsic Antibiotic Resistance Mechanisms of Gram-Negative Bacteria. Adv. Sci. 2019, 6, 1802333. [CrossRef]

159. Kamaraj, M.; Dhana Rangesh Kumar, V.; Nithya, T.G.; Danya, U. Assessment of Antioxidant, Antibacterial Activity and Phytoactive Compounds of Aqueous Extracts of Avocado Fruit Peel from Ethiopia. Int. J. Pept. Res. Ther. 2020, 26, $1549-1557$. [CrossRef]

160. Quiles, J.L.; Rivas-García, L.; Varela-López, A.; Llopis, J.; Battino, M.; Sánchez-González, C. Do nutrients and other bioactive molecules from foods have anything to say in the treatment against COVID-19? Environ. Res. 2020, 191, 110053. [CrossRef]

161. Russo, M.; Moccia, S.; Spagnuolo, C.; Tedesco, I.; Russo, G.L. Roles of flavonoids against coronavirus infection. Chem. Biol. Interact. 2020, 328, 109211. [CrossRef]

162. Wu, Y.H.; Tseng, C.K.; Wu, H.C.; Wei, C.K.; Lin, C.K.; Chen, I.S.; Chang, H.S.; Lee, J.C. Avocado (Persea americana) fruit extract (2R,4R)-1,2,4-trihydroxyheptadec-16-yne inhibits dengue virus replication via upregulation of NF- $\mathrm{kB}$-dependent induction of antiviral interferon responses. Sci. Rep. 2019, 9, 1-10. [CrossRef]

163. Martins, C.M.; Ferro, D.M.; de Brito, E.S.; Ferreira, S.R.S. Industrial relevance of Tamarindus indica L. by-products as source of valuable active metabolites. Innov. Food Sci. Emerg. Technol. 2020, 66, 102518. [CrossRef]

164. Menezes, A.P.P.; Trevisan, S.C.C.; Barbalho, S.M.; Guiguer, E.L. Tamarindus indica L. A plant with multiple medicinal purposes. J. Pharmacogn. Phytochem. 2016, 5, 50-54.

165. Martinello, F.; Kannen, V.; Franco, J.J.; Gasparotto, B.; Sakita, J.Y.; Sugohara, A.; Garcia, S.B.; Uyemura, S.A. Chemopreventive effects of a Tamarindus indica fruit extract against colon carcinogenesis depends on the dietary cholesterol levels in hamsters. Food Chem. Toxicol. 2017, 107, 261-269. [CrossRef]

166. Sarkar, A.; Ghosh, U. Optimization of the extraction of natural phenolic antioxidants from the seeds of Tamarindus indica L.-An undervalued by product of food processing-Using response surface methodology. Acta Biol. Szeged. 2018, 62, 67-74. [CrossRef]

167. Nikooei, P.; Hosseinzadeh-Attar, M.J.; Asghari, S.; Norouzy, A.; Yaseri, M.; Vasheghani-Farahani, A. Effects of virgin coconut oil consumption on metabolic syndrome components and asymmetric dimethylarginine: A randomized controlled clinical trial. Nutr. Metab. Cardiovasc. Dis. 2021, 31, 939-949. [CrossRef]

168. Maduwanthi, S.D.T.; Marapana, R.A.U.J. Total phenolics, flavonoids and antioxidant activity following simulated gastro-intestinal digestion and dialysis of banana (Musa acuminata, AAB) as affected by induced ripening agents. Food Chem. 2021, $339,127909$. [CrossRef]

169. Sidhu, J.S.; Zafar, T.A. Bioactive compounds in banana fruits and their health benefits. Food Qual. Saf. 2018, 2, 183-188. [CrossRef]

170. Sansone, R.; Rodriguez-Mateos, A.; Heuel, J.; Falk, D.; Schuler, D.; Wagstaff, R.; Kuhnle, G.G.C.; Spencer, J.P.E.; Schroeter, H.; Merx, M.W.; et al. Cocoa flavanol intake improves endothelial function and Framingham Risk Score in healthy men and women: A randomised, controlled, double-masked trial: The Flaviola Health Study. Br. J. Nutr. 2015, 114, 1246-1255. [CrossRef]

171. Lin, X.; Zhang, I.; Li, A.; Manson, J.A.E.; Sesso, H.D.; Wang, L.; Liu, S. Cocoa flavanol intake and biomarkers for cardiometabolic health: A systematic review and meta-analysis of randomized controlled trials. J. Nutr. 2016, 146, 2325-2333. [CrossRef] 
172. Davinelli, S.; Corbi, G.; Zarrelli, A.; Arisi, M.; Calzavara-Pinton, P.; Grassi, D.; De Vivo, I.; Scapagnini, G. Short-term supplementation with flavanol-rich cocoa improves lipid profile, antioxidant status and positively influences the AA/EPA ratio in healthy subjects. J. Nutr. Biochem. 2018, 61, 33-39. [CrossRef] 
173. Álvarez-Cilleros, D.; López-Oliva, M.E.; Ramos, S.; Martín, M.Á. Preventive effect of cocoa flavanols against glucotoxicity-induced vascular inflammation in the arteria of diabetic rats and on the inflammatory process in TNF- $\alpha$-stimulated endothelial cells. Food Chem. Toxicol. 2020, 146, 111824. [CrossRef]

174. Vázquez-González, Y.; Ragazzo-Sánchez, J.A.; Calderón-Santoyo, M. Characterization and antifungal activity of jackfruit (Artocarpus heterophyllus Lam.) leaf extract obtained using conventional and emerging technologies. Food Chem. 2020, $330,127211$. [CrossRef] 